\title{
ALEXANDER GEORG SUPAN - V SLOVENIJI SPREGLEDAN GEOGRAF SLOVENSKEGA RODU
}

\author{
dr. Dejan Cigale*, dr. Darko Ogrin* \\ * Oddelek za geografijo, Filozofska fakulteta Univerze v Ljubljani \\ Aškerčeva 2, SI- 1000 Ljubljana \\ e-pošta: dejan.cigale@ff.uni-lj.si, darko.ogrin@ff.uni-lj.si \\ Pregledni znanstveni članek \\ COBISS 1.02 \\ DOI: $10.4312 /$ dela.45.8.135-163
}

\section{Izvleček}

Prispevek predstavlja življenje in delo Alexandra Supana, geografa slovenskega rodu ter njegov vpliv na svetovno in slovensko geografijo. Sodil je med pomembnejše geografe druge polovice 19. in začetka 20. stoletja. Njegovo znanstveno delo je potekalo, za razliko od geografov, delujočih na Slovenskem, v skladu s takratnimi modernimi usmeritvami. Kariero je zgradil na tujem, začel pa jo je v Ljubljani. Zaradi tega in njegovega rodu ga lahko upravičeno uvrščamo med pomembnejše člene zgodovine moderne geografije na Slovenskem.

Ključne besede: Alexander Georg Supan, zgodovina moderne geografije, razvoj slovenske geografije, darvinizem, okoljski (geografski) determinizem, geopolitika

\section{ALEXANDER GEORG SUPAN - GEOGRAPHER OF SLOVENIAN ORIGIN, OVERLOOKED IN SLOVENIA}

\begin{abstract}
Paper presents life and work of Alexander Supan, geographer of Slovenian origin, and his influence on global and Slovenian geography. He was one of the more important geographers of the second half of the 19th and at the beginning of the 20th century. His scientific work took place, in contrast to geographers who were then working in present-day Slovenian territory, in accordance with contemporary geographic approaches. He built his career abroad, but he started it in Ljubljana. Because of that and because of his origin, we can consider him one of the more important links in the history of modern geography in Slovenian territory.
\end{abstract}

Key words: Alexander Georg Supan, history of modern geography, development of Slovenian geography, darwinism, environmental (geographical) determinism, geopolitics 


\section{UVOD}

Leta 2020 bo minilo 100 let, kar je umrl Alexander Georg Supan. Rodil se je na Južnem Tirolskem, vendar slovenskim staršem, materi Antoniji iz Radovljice in očetu Jakobu iz Zasipa pri Bledu, ki je na Tirolskem služboval kot gozdar. Supan je svojo poklicno pot začel kot učitelj geografije in zgodovine na ljubljanski realki, znanstveno kariero pa si je zgradil na tujem. Bil je eden najbolj vplivnih geografov svojega časa. O njegovem strokovnem in znanstvenem pomenu priča tudi to, da najdemo gesla z njegovim imenom v številnih publikacijah enciklopedičnega tipa. Mednje sodijo npr. Avstrijski biografski leksikon (Österreichisches Biographisches Lexikon ..., 2015), Enciklopedija Britannica (izdaja iz leta 1922; Encyclopedia Britannica ..., 1922), Velika sovjetska enciklopedija (Большая Советская Энциклопедия ..., 1952) in Wikipedija (2015). V slednji je geslo Alexander Supan prisotno v šestih jezikih (danskem, gruzijskem, nemškem, romunskem, ruskem, švedskem), med njimi pa ni slovenščine. Za Supana je nemški geograf in kartograf Hermann Wagner (1840-1929) ob njegovi smrti zapisal, da je bil »eden najodličnejših geografov« tedanjega časa, ki se je »nesebično, z železno marljivostjo in občudovanja vredno vztrajnostjo postavil v službo naši vedi« (Wagner, 1920, str. 139).

Kljub velikemu odzivu, ki ga je Supan doživel v mednarodnih geografskih in tudi geopolitičnih krogih, je njegovo delo v slovenskem prostoru le šibko odmevalo. Njegovo življenje in delo je slovenski geografski in drugi javnosti predstavil le Kranjec v Geografskem vestniku (Kranjec, 1963) in v Slovenskem biografskem leksikonu (Kranjec, 1971). Kranjec je podatke za svoja prispevka črpal predvsem iz dveh besedil, ki sta izšli o Supanu ob njegovi smrti (Wagner, 1920 in Dietrich, 1921), te podatke pa je dopolnil še z nekaterimi drugimi (npr. letna poročila realke v Ljubljani, katalogi bivše klasične gimnazije ...), ki so se nanašali predvsem na Supanova mlajša leta. Supan ni zastopan v prvem pregledu razvoja slovenske geografije (Bohinec, 1925), niti ne v kasnejših pregledih ob okroglih obletnicah slovenske znanstvene geografije (npr.: Ilešič, 1969) ali v razpravah o predhodnikih in začetnikih slovenske znanstvene geografije (npr.: Gams, 1992). Spregledan je bil tudi v Vrišerjevih izdajah Uvoda v geografijo (Vrišer, 1969; 1976; 1982; 1987; 1992; 1998; 2002). Najdemo pa ga v hrvaškem Uvodu v geografijo (Vresk, 1997). Eden od možnih vzrokov, da je bil pri nas zapostavljen, je njegova privrženost nemštvu. Kranjec (1963) domneva, da se je Supan v višji gimnaziji še čutil Slovenca (v gimnazijskih poročilih je zapisan kot Zupan, njegova sošolca sta bila narodnjaka Jakob Aljaž in Josip Jurčič), a ga je potem za »nemško stvar« navdušil najstarejši brat Josip Supan (18281902). Josip Supan, ki je bil tudi ljubljanski župan, je bil sprva naklonjen slovenskim težnjam in je bil ustanovni član Slovenske matice, a se je že leta 1866 obrnil na nemško stran in postal voditelj kranjskih Nemcev (Kranjec, 1963).

Namen prispevka je osvežiti spomin na življenje in delo Alexandra Supana, utrditi njegovo mesto v zgodovini geografije na Slovenskem ter predstaviti odmevnost in vpliv njegovega dela na svetovno in slovensko geografijo. Menimo, da je kljub temu, da se je čutil Nemca, tudi pomemben del zgodovine slovenske geografije. Bil je slovenskega rodu, v Ljubljani je končal gimnazijo, na ljubljanski realki je med letoma 1869 in 1877 poučeval zgodovino in geografijo. V času učiteljevanja v Ljubljani se je njegovo tehtanje 
med zgodovino in geografijo dokončno nagnilo v prid slednji. Kljub skromni šolski praksi se je tega leta tudi lotil pisanja učbenika geografije po načelih tedaj nastajajoče moderne geografije in ga $v$ Ljubljani tudi izdal.

Večji del prispevka predstavlja prikaz Supanovega življenja in dela ter njegove odmevnosti med Supanovimi sodobniki pa tudi v današnjem času. Splošni biografski in deloma tudi bibliografski podatki so povzeti - kjer drugače ni navedeno - po Wagnerjevem (1920) in Dietrichovem (1921) prispevku, ki sta nastala ob Supanovi smrti. Identične navedbe, čeprav v precej skrčeni obliki, je mogoče najti tudi v nekaterih (zgoraj omenjenih) delih enciklopedičnega tipa. Za lažjo umestitev in boljše razumevanje pomena Supanovega dela $\mathrm{z}$ vidika tedanjega stanja svetovne in slovenske geografije sta $\mathrm{v}$ začetnem delu prispevka še poglavji o splošnem razvoju geografije v 19. in na začetku 20. stoletja ter stanju slovenske geografije v tem času.

\section{RAZVOJ GEOGRAFIJEV 19. STOLETJU}

\section{I Prva polovica 19. stoletja in nastanek moderne geografije}

V 19. stoletju je dobila geografija novo vsebino in nove teoretične osnove. Razvoj je bil zelo zapleten, vendar najpomembnejši v njeni zelo dolgi zgodovini. V času velikih geografskih odkritij, pa tudi v 18. stoletju, je bila glavna naloga geografije odkrivanje novih, nepoznanih ali manj poznanih delov sveta, njihovo opisovanje, merjenje in kartografsko prikazovanje. Bila je veda, ki je ponujala uporabne informacije o Zemlji, pri čemer se je prepletala z ostalimi vedami, tako naravoslovnimi kot družboslovnimi. Iz nje so se razvile mnoge vede in znanstvene discipline, ki so tudi imele za predmet proučevanja Zemljo kot nebesno telo. V začetku 19. stoletja se je začel proces postopnega osamosvajanja geografije kot vede, predvsem trganja tradicionalnih povezav z zgodovino.

Velika geografska odkritja so prinesla veliko novih spoznanj in obsežno faktografsko gradivo. Družbeni in znanstveni razvoj v 19. stoletju je izpostavil potrebo, da se to gradivo obdela in prikaže s pomočjo novih geografskih konceptov in teoretičnih osnov, saj so prejšnji preživeli. Novo nastajajoča geografija se je začela postopno usmerjati k raziskovanju temeljnih naravnih in družbenih pojavov, ki sestavljajo Zemljino površje, in v pojasnjevanje njihovih medsebojnih odvisnosti. Družbene potrebe po novih znanjih o pojavih in procesih na Zemljinem površju so pripeljale do hitrega razvoja tudi v mnogih geografiji sorodnih vedah, npr. v geologiji, biologiji, astronomiji, statistiki, ekonomiji, sociologiji in etnologiji. To je pripeljalo geografijo v položaj, da je morala na novo definirati in zamejiti svoj predmet proučevanja kakor tudi teoretične in metodološke osnove. V teoretičnem pogledu je geografija vstopila v novo obdobje poglobljenih razprav o svojih idejnih osnovah, tudi med seboj nasprotujočih si, od materialističnih do idealističnih. Te razprave so bile $\mathrm{v}$ osnovi nadaljevanje razprav iz predhodnega obdobja razvoja geografije, le da so potekale pod vplivom novih socioloških in filozofskih pogledov.

Vpliv francoskega materializma se je $\mathrm{v}$ geografiji odrazil $\mathrm{v}$ mehaničnem materializmu in $\mathrm{v}$ determinističnih konceptih razumevanja odnosa med naravo in človekom. Ta smer 
se je $\mathrm{v}$ glavnem razvila kot odgovor na predhodne teološke poglede, ki so izhajali še iz srednjega veka. Na drugi strani je bil zelo velik tudi vpliv Heglovih filozofskih konceptov. Za geografijo je bil pomemben predvsem njegov pristop $\mathrm{k}$ raziskovanju pojavov, ki je opravil z metafizičnim razumevanjem sveta. Koliko so bila ta razmišljanja pomembna za utemeljitev moderne geografije in njen nadaljnji razvoj je najbolj razvidno iz del nemških geografov Alexandra von Humboldta (1769-1859) in Carla Ritterja (1779-1859), prvih predstavnikov t. i. moderne geografije, ki sta začrtala pot razvoja geografije v prvi polovici 19. stoletja. Prva sta bila, ki sta izhajala iz opazovanja in pojasnjevanja vzročnih povezav in odnosov med geografskimi pojavi in procesi v prostoru in času ter tako opredelila predmet in naloge moderne geografije. Njuno razumevanje geografije je sledilo Kantovemu horološkemu (prostorskemu) pristopu, metodološko pa primerjalni metodi. Ideološko sta bila na različnih bregovih. Humboldt je bil kot naravoslovec materialističnega, Ritter pa kot teolog in zgodovinar idealističnega nazora. Humboldt je na svojih raziskovalnih ekspedicijah zbral ogromno gradiva, na katerem je utemeljil svoja spoznanja, predvsem s področja fizične geografije. Velik pomen je pripisoval meritvam in številčnim podatkom, odkrivanju zakonitosti in vzročnim odvisnostim med naravnimi pojavi v različnih delih sveta. Na ta način je proučeval tudi odnos med naravo in človekom. V svojem najbolj znanem delu Kosmos (1845-1862), v katerem je poskusil zaobjeti takratno poznavanje naravnih razmer na Zemlji, poudarja, da se posamezno lahko spozna samo kot del celote ter tako izpostavi kompleksni in sintetični značaj geografije, $\mathrm{s}$ tem pa njeno specifičnost v primerjavi z drugimi vedami (Geoffrey in sod., 1993).

Nasprotno pa Ritterjevi zaključki ne izhajajo iz neposrednih opazovanj naravnih pojavov, ampak iz poročil drugih raziskovalcev in analize zgodovinskih dejstev. Na njihovi podlagi je poskušal pojasniti vlogo naravnih pogojev za zgodovinski razvoj posameznih narodov. Po njegovem je zgodovina narodov pogojena z naravnimi razmerami. Kot idealist je poudarjal, da je Zemlja »dom za vzgojo človeka, kjer se odvija njegova zgodovina« in da se »človeška zgodovina odvija po vnaprej določenem načrtu«. Njegovi pogledi so zelo blizu okoljskemu (geografskemu) determinizmu. Mnenja je, da so pokrajinske prvine $\mathrm{v}$ prostorskih enotah $\mathrm{v}$ takih medsebojnih povezavah, da so posamezne pokrajine individualni, neponovljivi deli Zemljinega površja. Poudarjal je, da morajo sinteze in opisi geografskih enot izhajati iz predhodnih analiz pokrajinskih elementov. Proučevanje geografskih enot je po Ritterju osnovna naloga geografije. Kot osnovno enoto za proučevanje je imel kontinente, zato so njegove ugotovitve pogosto pretirano posplošene. Ker je želel razložiti povezave in odnose v pokrajini in ne jih samo opisati, je svojo novo znanstveno geografijo raje poimenoval »Erdkunde« (znanost o Zemlji) in ne »Erdbeschreibung« (opis Zemlje), kot je geografijo imenoval Humboldt. Njegovo najpomembnejše delo je zbirka 19 knjig Die Erdkunde im Verhältniß zur Natur und zur Geschichte des Menschen oziroma Geografija v odnosu do narave in do zgodovine človeka, od katere je prvi dve knjigi objavil leta 1817 in 1819, druge pa kasneje (Geoffrey in sod., 1993).

Kljub določenim razlikam imata Humboldt in Ritter v nekaterih splošnih pogledih na geografijo veliko skupnega. Oba razumeta geografijo kot posebno vedo, ki ima za osnovno nalogo celovito predstavitev pokrajin, vključno z rezultati človekovega dela in načinom življenja (življenjskim stilom). Geografijo vidita kot enotno vedo, z enim 
predmetom proučevanja, ki se notranje deli na občo in posebno (regionalno). Za Ritterja so predmet geografskega proučevanja konkretne prostorske enote (pokrajine, regije), ki jih sestavljajo narava, prebivalstvo in gospodarstvo. Ritter je imel na nadaljnji razvoj geografije večji vpliv od Humboldta, saj je bil leta 1820 imenovan za profesorja geografije na univerzi v Berlinu. Zgradil je lastno geografsko šolo, po kateri se je zgledovala nemška in tudi svetovna geografija.

\subsection{Druga polovica 19. stoletja in začetek 20. stoletja ter vpliv darvinizma}

S smrtjo Humboldta in Ritterja se je po mnenju Holt-Jensena (1981) zaključilo klasično obdobje razvoja moderne geografije. Humboldt in Ritter sta na temeljih, ki jih je že prej kot predavatelj fizične geografije v Königsbergu postavil Immanuel Kant (17241804), moderno geografijo umestila v sistem znanosti kot samostojno vedo. Dodelala sta njene osnove in utrdila prepričanje, da mora veda temeljiti na objektivnih ugotovitvah, ki izhajajo iz opazovanj, in ne le na logičnih predpostavkah. Po njuni smrti leta 1859 so se v geografiji začele pojavljati različne smeri in pogledi, od evolucionizma in pozitivističnega pristopa do okoljskega determinizma in posibilizma, prisotne so bile tako dezintegracijske težnje kot posledica hitrejšega razvoja posameznih geografskih disciplin, kakor tudi integracijske s poudarjanjem pomena sinteze. Še naprej so bili močno zastopani tudi Ritterjevi pogledi, ki so jih širili njegovi številni učenci in zagovarjali zgodovinske poglede na geografijo ter izpostavljali pomen regionalne geografije.

Velik vpliv na razvoj geografije, kakor tudi drugih ved, predvsem naravoslovnih, je imel v drugi polovici 19. stoletja Charles Darwin (1809-1892), predvsem njegovo delo O izvoru vrst (1859). Pod njegovim vplivom sta Ritterjev teološki pristop postopoma zamenjala materialistična filozofija in evolucijski pristop s poudarkom na odkrivanju naravnih zakonov in vzročnosti. Privrženci darvinizma so poskušali celo razvrednotiti Ritterjevo delo in mu odrekali znanstvenost, saj ga niso mogli postaviti v Darwinov koncept boja in preživetja. V naravoslovju se je uveljavil empirijski pristop s postavljanjem hipotez in njihovim preverjanjem, kar je vodilo k oblikovanju splošnih spoznanj in zakonov. $\mathrm{V}$ geografiji je pod vplivom vsesplošnega razvoja naravoslovja močno napredovala fizična geografija, ki je svoja spoznanja začela nadgrajevati na temeljih, ki sta jih postavila Humboldt in škotska geografinja Mary Somerville (1780-1872). Vpliven je bil predvsem njen učbenik fizične geografije (Physical Geography), ki je izšel leta 1848 in je bil v uporabi do začetka 20. stoletja.

V zadnji tretjini 19. stoletja se je za fizično geografijo uveljavilo ime fiziografija (physiography). Obsegala je širše področje kot danes, definirali bi jo lahko kot »opis narave« ali, kakor je svoj učbenik iz fizične geografije poimenoval slovenski geograf Janez Jesenko (1838-1908), »Prirodoznanski zemljepis« (1874). Po zaslugi naravoslovcev, ki so se ukvarjali s fizično geografijo, je geografija tudi dobila ustrezno mesto na univerzah in postala priljubljen študij. Velikega pomena za razmah univerzitetne geografije je bila odločitev pruske vlade, da mora potekati študij geografije na vseh univerzah, saj je v geografiji prepoznala znanja, pomembna za bodočnost države. Veliko večino fizične 
geografije je konec 19. stoletja zavzemala geomorfologija (v tem času je bil zanjo v splošni rabi izraz »morfologija«), zaradi česar je ponekod prišlo tudi do teženj, da postane fiziografija (fizična geografija) del novo nastale geologije (Holt-Jensen, 1981).

Razen dezintegracijskih teženj, ki so izhajale predvsem iz prevladujočega evolucionizma in pozitivističnega pristopa $\mathrm{k}$ raziskovanju ter teženj po osamosvajanju fizične geografije in njenih posameznih disciplin, so bile $\mathrm{v}$ drugi polovici 19. stoletja $\mathrm{v}$ geografiji v manjši meri prisotne tudi integracijske težnje s poudarjanjem potrebe po sintezi pri proučevanju procesov in pojavov na Zemljinem površju in zagovarjanjem geografije kot horološke vede, kar je bil prevladujoč trend v razvoju geografije v prvi polovici 20. stoletja. Zaradi dezintegracijskih teženj je zašla komaj nastala znanstvena geografija $\mathrm{v}$ težave glede razmejevanja $\mathrm{z}$ ostalimi vedami, predvsem geologijo in biologijo. $\mathrm{Z}$ osamosvojitvijo geologije, geofizike in geodezije se je tudi predmet geografskega proučevanja skrčil samo na površinske dele Zemljinega površja.

Po Stoddartu (1966) so v geografiji naletele na odziv predvsem štiri Darwinove ideje:

- razvoj pojavov skozi čas ali evolucija;

- odnosi med živimi bitji in povezave med njimi ter njihovim okoljem;

- selekcija in boj za preživetje;

- naključnost v razvoju živih bitij.

Evolucija je splošen koncept postopnega, enakomernega razvoja od nižjih, bolj preprostih, proti višjim, bolj zapletenim oblikam. Ideja je močno vplivala na raziskovanje reliefa. Na njej je Darwin oblikoval teorijo o razvoju koralnih grebenov. Najbolj znan primer prenosa te ideje v geografijo je Davisov model cikličnega razvoja reliefa, v katerem razlaga razvoj površja skozi mlado, zrelo in staro fazo (Bognar, 2001; Natek, 2001). Podobne razlage so se pojavile tudi v pedologiji in ekologiji, evolucijsko idejo je pri razlaganju razvoja kulturne pokrajine skozi čas uporabila tudi francoska regionalnogeografska šola v začetku 20. stoletja (Stoddart, 1966).

Darwinova razmišljanja o odnosih med živimi bitji, povezavah med njimi ter njihovim okoljem (združbe) so bila osnova za nastanek nove vede - ekologije. Darwin je obravnaval človeka kot del žive narave in kot tak je postal sestavni del ekoloških raziskav. V začetku 20. stoletja se je za študij odnosov človeka in njegovega okolja uveljavilo ime humana ekologija, ki je našla svoje delovno področje tudi znotraj geografije. Analogija z živimi organizmi in njihovo organizacijo je v geografiji zaznavna tudi pri obravnavi regij in držav. Herbertson (1913-1914, cit. po Stoddart, 1966; Andrew John Herbertson, 1865-1915, je bil britanski geograf) je naravne regije (pokrajine) razumel kot združbe anorganske in žive materije z vsemi njihovimi funkcijami in strukturami. Tako kot rastline in živali lahko po njegovem prepričanju tudi regije hierarhično razvrščamo v vrste, rodove, redove in razrede, na kar se je opirala metodologija angleške regionalne geografije $\mathrm{v}$ prvi polovici 20. stoletja.

Darvinizem je močno pospešil proučevanje razmerja med naravo in človekom. Britanski filozof Herbert Spencer (1820-1903) ima zasluge za uvedbo t. i. socialnega darvinizma. Prepričan je bil, da je človeška družba zelo podobna živalskim in da se morajo človeške družbe bojevati, če želijo preživeti v določenem okolju. Spencer je bil liberalec 
in je verjel, da bo najmočnejši posameznik najbolje in najlažje preživel v svobodni, tržni ekonomiji. Pod vplivom teh idej je bil tudi Friedrich Ratzel (1844-1904), ki je v delu Antropogeografija (Anthropogeographie, 1882) vpeljal takratne poglede naravoslovja v družbeno geografijo. Antropogeografijo je razumel kot del biogeografije, družbeni razvoj pa razlagal kot posledico naravnih razmer, saj relief, prst, vodovje, temperatura in vegetacija pogojujejo prostorsko razporeditev poselitve. Delo je izšlo v času, ko je bila geografija izrazito usmerjena $v$ fizično geografijo, zato lahko Ratzla upravičeno štejemo za utemeljitelja družbene geografije, kljub očitkom, da je družbene in prostorske procese razlagal izrazito deterministično (Bufon, 2001). Determinizma se je oklepal tudi Ellsworth Huntington (1876-1947), ki je razlagal vzpon civilizacij v zmernih geografskih širinah in slabšo razvitost $\mathrm{v}$ nizkih geografskih širinah $\mathrm{z}$ manj ugodnim podnebjem $\mathrm{v}$ tropskem pasu.

Idejo, da je človeška družba podobna živalskim združbam, je Ratzel še bolj razgradil v Politični geografiji (Politische geographie,1897). Tu razpravlja o državi kot organizmu, ki je pripet na določeno območje (celovitost države in njenega ozemlja), države pa se v skladu z Darwinovim naukom med seboj borijo za preživetje, kjer preživijo najmočnejše in najprilagodljivejše. Hranilo držav, tako kot hrana in voda pri organizmih, so nova ozemlja. Koncept o vrstnem boju in naravni selekciji je imel velik odziv tudi $v$ tedanjih političnih idejah liberalnih ekonomistov. Z idejo so opravičevali kolonializem in težnjo večjih narodov (držav) po prevladi nad manjšimi. Ti pogledi so bili odločilni tudi za geopolitični razvoj v Evropi med obema svetovnima vojnama.

Darwinove ideje so $\mathrm{v}$ geografskih krogih interpretirali v determinističnem smislu. Iz verskih in znanstvenih razlogov (zakoni o dednih spremembah, tudi mutacijah, so bili odkriti šele kasneje) je bil zanemarjen koncept naključnosti. To idejo so začeli geografi pogosteje uporabljati šele sredi 20. stoletja. Avtorji, ki razvoj geografije razlagajo s pomočjo Kuhnovega modela razvoja znanosti (Holt-Jensen, 1981; Stoddart, 1981; Vresk, 1991), so mnenja, da je s splošnim sprejetjem Darwinovih pogledov v vseh najpomembnejših geografskih šolah geografija prešla $\mathrm{v}$ drugi polovici 19. stoletja iz predparadigmatske $\mathrm{v}$ prvo paradigmatsko fazo. Za predparadigmatsko fazo razvoja je značilno, da prevladujejo posamezne geografske šole, od katerih vsaka zastopa svoj pogled, in da veda nima enotnih teoretskih in metodoloških izhodišč za reševanje znanstvenih vprašanj. Med posameznimi šolami, znanstveniki in tudi laiki sicer poteka komunikacija, vendar so zelo pogosti konflikti o osnovnih idejnih in metodoloških usmeritvah stroke.

$\mathrm{S}$ prevlado determinizma in geomorfologije $\mathrm{v}$ vseh pomembnejših geografskih okoljih je geografija vstopila $v$ prvo paradigmatsko fazo razvoja. $V$ tej fazi, v kateri se je utrdil ugled geografije, je veda zdržala skoraj polovico stoletja. V krizo je zašla, ko so se začele pojavljati številne kritike determinizma, saj z njim ni bilo možno zadovoljivo pojasniti vedno več znanstvenih in strokovnih vprašanj. Kot oponent stari paradigmi se je uveljavil posibilizem, ki skupaj z vzponom regionalne geografije predstavlja drugo paradigmatsko fazo. Ta je prevladovala med obema svetovnima vojnama. Privrženci posibilizma, ki ga je zagovarjal francoski zgodovinar Lucien Febvre (1878-1956), so glede odnosa med naravo in človeško družbo zagovarjali pogled, da ni nobene nujnosti, ampak le možnosti. Dopuščali so možnost, da narava omejuje človeka, vendar so bolj poudarjali človekovo odločitev za izvajanje dejavnosti kot pa okoljske omejitve. 
Za uveljavitev posibilizma v geografiji in regionalne geografije je bil najbolj zaslužen Paul Vidal de la Blache (1845-1919). Francoskim geografom so nato sledile še nemška, britanska in ruska geografska šola. Vidal de la Blache je nasprotoval pretiranim in včasih nesmiselnim generalizacijam, ki so se pojavljale v številnih splošnih geografijah, in Ratzlovim determinističnim nazorom. Kot protiutež je izpostavil potrebo po proučevanju razmerja med človekom in njegovim okoljem v manjših pokrajinah (pays), kjer ni veliko možnosti, da bi se geograf bistveno oddaljil od stvarnosti. Njegove pobude je sprejela vrsta geografov. Realizirali so jih v številnih, tehtno zasnovanih regionalnogeografskih monografijah. Najlepši primer je zbirka Geographie universelle, v kateri so zbrane regionalne geografije vseh poglavitnih svetovnih regij. Vidal de la Blachev osnovni pristop k proučevanju človeka in njegovega okolja (dveh glavnih komponent geografskega študija) je bil, da narava določa omejitve in nudi možnosti za poselitev in življenje človeka, način, kako se človek odziva in si prilagaja naravo, pa je odvisen od njegovih sposobnosti, tradicije in načina življenja. Po njegovem mnenju je nesmiselno postavljati meje med naravnimi in družbenimi pojavi v pokrajini, ampak jih je potrebno proučevati kot celoto. Težišče geografskega raziskovanja je po njegovem prepričanju način življenja (genre de vie), ki ga izoblikujejo skupine ljudi v svojem okolju. Način življenja kot oblika prilagoditve ljudi na geografsko okolje je tudi kriterij za členitev na pokrajine (Geoffrey in sod., 1993). Izhodiščem francoskega posibilizma se je pri svojem regionalnogeografskem proučevanju približal tudi Anton Melik. Pri proučevanju pokrajine se je osredotočal na razvojno, historično naravnano raziskovanje, kjer je izstopal segment naravnih razmer. Po eni strani je hotel prikazati naravne razmere, ki določajo delovanje človeka, od poselitve do gospodarske usmerjenosti, po drugi pa kot dejavnik, ki ga človek spreminja in vanj posega (Ilešič, 1960).

\subsection{Geografija na Slovenskem v 19. stoletju in na začetku 20. stoletja}

V 19. stoletju je geografija v najbolj razvitih okoljih naredila preobrat od do tedaj prevladujoče deskripcije k znanstvenemu razpravljanju o problemih. V začetnem obdobju je zelo napredovala fizična geografija, zlasti geomorfologija, na Ratzlovo pobudo se je začela razvijati tudi »antropogeografija«. Njene deterministične poglede je kmalu spremenila francoska posibilistična šola Vidal de la Blacha. Ob obeh prevladujočih pogledih je napredovalo tudi kompleksno, ne samo opisujoče, ampak tudi pojasnjujoče obravnavanje pokrajinske stvarnosti kot celote. Ta klasična regionalna geografija je, razen pri francoskih regionalistih Vidal de la Blacheve šole, našla veliko pristašev v »primerjalnem deželoslovju « (vergleichende Länderkunde) Alfreda Hettnerja in njegovih učencev, od katerih je na naše ozemlje s svojo regionalno geografijo Vzhodnih Alp (Die Ostalpen und das heutige Österreich: eine Länderkunde, 1928) posegel zlasti Norbert Krebs (1876-1947).

Medtem ko je v razvitih geografskih okoljih v Evropi in svetu v 19. stoletju geografija kot znanost prešla iz predparadigmatske v paradigmatsko fazo razvoja, so pri nas za geografska označevali dela z domoznansko, potopisno, kronistično in podobno tematiko (Bohinec, 1925; Ilešič, 1979). Z izjemo nekaj posameznikov, med katere moramo vsekakor šteti tudi Alexandra Supana, ki pa znanstvene kariere ni zgradil v slovenskem 
prostoru, geografije v novem smislu tako rekoč nismo poznali. Dejstvo ni presenetljivo, saj nismo imeli univerzitetnega središča ali druge organizacije, npr. geografskega društva, ki bi načrtno gojilo znanstveno geografijo in sledilo sodobnim tokovom. Višjo razvojno stopnjo je dosegla šolska geografija, kjer so se z učbeniki uveljavili Vincencij Fereri Klun (1832-1875), Blaž Kocen (1821-1871), slednji tudi kot izvrsten kartograf (Blaž Kocen 1821-1871, 2009; Bratec Mrvar, 2002) ter Fran Orožen (1853-1912). V večji meri so pogledi moderne evropske geografije $\mathrm{k}$ nam začeli prodirati šele $\mathrm{v}$ dvajsetih letih 20. stoletja s študenti, ki so študirali na Dunaju, med njimi z Antonom Melikom (1890-1966), in z deli Jovana Cvijića (1865-1927) iz Beograda.

Po Bohincu (1925) je temelje slovenskemu domoznanstvu položil Dragotin Dežman (1821-1889) s svojimi prispevki k naravoslovju Kranjske, v katerih je pisal o podnebju Kranjske, o sledovih poledenitve, opisal je Polhograjsko hribovje ter »Notranjske gore in Cirkniško jezero« (Bohinec, 1925, str. 7). Veliko je k poznavanju slovenskih pokrajin še pred njim prispeval tudi Henrik Freyer (1802-1866), ki je bil tako kot Dežman več let kustos ljubljanskega muzeja. Raziskoval je rastlinstvo, živalstvo in kraške jame, zbiral je tudi topografske podatke za Zemljevid vojvodine Kranjske. Še več geografskih (ali tudi geografskih) domoznanskih del je izšlo po letu 1848, ko je dobilo slovensko narodno gibanje zagon. Mihael Peternel (1808-1884), učitelj prirodopisnih ved na ljubljanski realki, je v nemškem jeziku napisal kratek, a temeljit geografski opis Kranjske, raziskoval je tudi gospodarskogeografske razmere na Kranjskem. Pomembno je delo Petra Kozlerja (1824-1879), enega od ustanoviteljev Slovenskega zbora Slovenije, ki si je zadal za politični cilj, »da se vse pokrajine, koder stanujejo Slovenci, združé v jedno upravno enoto - zjedinjeno Slovenijo « (Bohinec, 1925, str. 10). Za dosego tega cilja je raziskoval meje poselitve s Slovenci, zbiral slovenska krajevna imena in po večletnih težavah z oblastmi leta 1861 le izdal Zemljovid slovenske dežele in pokrajin. Kot dopolnilo zemljevidu je napisal Kratek slovenski zemljopis in pregled politične in pravosodne razdelitve ilirskega kraljestva in štajerskega vojvodstva s pridanim slovenskim in nemškim imenikom mest, tergov, krajev i.t.d. (1854). Delo na popisu vseh slovenskih dežel je po ustanovitvi leta 1863 nadaljevala Slovenska matica, najprej s prevodi nemških del, kjer sta se izkazala za velik problem nedodelanost in pomanjkanje slovenske geografske terminologije, kasneje pa z izdajanjem zbirke Slovenska zemlja, ki naj bi opisala vse naše pokrajine »v prirodoznanskem, kulturnem in zgodovinskem obziru« (Bohinec, 1925, str. 15).

Novi pogledi na geografijo so imeli v našem prostoru nekaj malega odmeva šele $\mathrm{v}$ drugi polovici 19. stoletja, najprej po zaslugi Janeza Jesenka in njegovih knjig Občni zemljepis (1873) in Prirodoznanski zemljepis (1874). Knjigi ne izhajata iz Jesenkovega raziskovalnega dela, tudi napisani sta za potrebe šolske geografije, vendar z upoštevanjem najpomembnejših del in usmeritev geografije $v$ tedanjem času, kjer je bil zelo velik poudarek na fizični geografiji. Širša zasnova tedanje fizične geografije od današnje se je odražala tudi $v$ šolstvu, kjer naj bi se poučevala kot nekakšen krovni predmet ali kakor je zapisal Jesenko v predgovoru k Prirodoznanskemu zemljepisu: »Ta poduk imel bi primerno skleniti in dovršiti vse prirodoslovno učenje na gimnaziji; zediniti bi namreč imel raznoverstne nauke o prirodi ter odraslim dijakom očitno pokazati enoto prirode in njenih raznoverstnih prikazni« (Jesenko, 1874, str. 3). Jesenkovo delo je pomembno tudi 
s terminološkega vidika, saj je z njim postavil osnove slovenski geografski terminologiji (Bratec Mrvar in sod., 2008).

Čeprav je bil namen Slovenske matice »skrbeti po svoji moči, da bi se širilo izobraževanje slovenskega naroda in da bi se podpiralo slovensko slovstvo«, izdajala naj bi »dobre, čisto znanstvene pa tudi ljudstvu primerjene spise « in je bila po mnenju Mahniča (2009) do ustanovitve Univerze v Ljubljani leta 1919 ter Slovenske akademije znanosti in umetnosti leta 1939 najvišja znanstvena ustanova, pa je svojo nalogo, kar se tiče znanstvene geografije, nepopolno opravila. Matica je sicer pospeševala zemljepisno dejavnost, imela je »zemljevidni« in »krajepisni odsek«, ki sta se leta 1910 združila v »zemljepisni odsek«, ki naj bi imel podobno vlogo kot razna geografska društva drugod po svetu (Kranjec, 1964, str. 210), vendar ni uspela ujeti takratnih sodobnih tokov v evropski geografiji. Tudi zaradi tega je imela slovenska znanstvena geografija, v nasprotju z nekaterimi drugimi vedami, ob ustanovitvi slovenske univerze leta 1919 težave, ker preprosto ni imela kvalificiranih ljudi, ki bi zastopali geografsko znanost na ravni, ki jo je ta dosegla $\mathrm{v}$ razvitem svetu.

Ilešič (1969) je bil predvsem presenečen, »kako je razvoj evropske geografije kot prerojene stroke z novimi znanstvenimi nameni nadvse šibko odseval v široko zasnovani zbirki zemljepisno-zgodovinskih knjig o slovenskih deželah, ki jih je Slovenska matica izdajala od devetdesetih let [19. stoletja] naprej pod naslovom Slovenska zemlja« (Ilešič, 1969, str. 232). Še največ teh odsevov vidi v delu Simona Rutarja o primorski in beneški Sloveniji ter Kamniških ali Savinjskih Alpah Ferdinanda Seidla (1907/1908), za druge pa meni, »da se njihovi avtorji še niso utegnili izkopati iz tradicionalne, preproste, čisto deskriptivne deželopisne sheme, modernizirane kvečjemu po kartografski strani« (Ilešič, 1969, str. 232). Ferdinanda Seidla (1856-1942) in njegova naravoslovna dela, npr. o podnebju Kranjske (Das Klima von Krain, 1891-1902), vidi tudi Bohinec (1925, str. 19) kot začetnika nove dobe v slovenski geografiji, »[k]akor je bil svojčas Peternel glasnik narodne geografije že nekaj desetletij, preden so se izživeli predmarčni nazori«. Podobno o njem meni tudi Gams (1992).

\section{SUPANOVO ŽIVLJENJE IN DELO}

Supan se je rodil 3. marca 1847 v San Candidu/Innichenu na Južnem Tirolskem v sedanji Italiji, umrl pa 6. julija 1920 v Wrocłavu (tedanji Breslau), Poljska (Encyclopedia Britannica ..., 1922; Österreichisches Biographisches Lexikon ..., 2015; Kranjec, 1971), po nekaterih navedbah pa v Gothi, Nemčija (TheFreeDictionary's Encyclopedia, 2015).

Že kot desetleten deček je prišel v Ljubljano in tam leta 1866 končal gimnazijo. Študij, in sicer zgodovine in literature, je nadaljeval v Gradcu, kjer je bil februarja 1870 promoviran za doktorja. Napravil je tudi učiteljski izpit iz zgodovine, geografije in nemščine. Od jeseni 1870 je poučeval na ljubljanski višji realki (Laibacher Oberrealschule). Postopoma ga je čedalje bolj pritegovala geografija, kar je razvidno tudi iz njegovega zapisa: »Ko pregledujem [revijo] Petermanns geographische Mitteilungen, iz dneva v dan bolj čutim, da je geografija moj pravi poklic ...« (Wagner, 1920, str. 140). Kasneje je sam postal urednik te revije. 
Leta 1873 je v letnem poročilu ljubljanske realke (Der Jahresbericht 1873 der Oberrealschule) izšel njegov prispevek Über den geographischen Unterricht an unseren Mittelschulen (O geografskem pouku v naših srednjih šolah). Kot navaja Kranjec (1963), Supan v njem graja podrejeno vlogo geografije v srednjih in visokih šolah ter kritizira stanje na področju geografije, $v$ kateri se je po njegovih besedah najdlje ohranila duhovna suša prejšnjih stoletij. Zagovarja tudi stališče, da se geografije ne da učiti med štirimi stenami, temveč je treba z učenci ven v naravo. Naslednje leto (1874) je v Ljubljani izšel njegov učbenik Lehrbuch der Geographie nach den Principien der neuren Wissenchaft für österrerichische Mittelschulen (Učbenik geografije po načelih novejše znanosti za avstrijske srednje šole).

Supan je v Ljubljani kmalu začutil »znanstveno izoliranost« (Wagner, 1920, str. 140), zato si je vzel dopust, da se je v Gradcu naprej izobraževal in šel na enoletno študijsko potovanje. Pri tem ga je pot vodila tudi v Halle, pomembno nemško univerzitetno središče, kjer je med drugim študiral geologijo. Spomladi 1877 se je vrnil v Ljubljano, kjer pa je - po Wagnerjevih (1920, str. 141) in Dietrichovih (1921, str. 193) navedbah - svojo učiteljsko službo občutil kot breme. Znova je dobil dopust in potovalno štipendijo, tako da je potem preživel en semester v Leipzigu, kjer je poslušal zoološka in astronomska predavanja. Od tam je pogosto obiskoval Halle. Na Dunaju je bil potem sprejet sklep o njegovi premestitvi na gimnazijo v mestu Černivci v današnji Ukrajini. Premestitev mu je ponudila možnost, da se je leta 1877 habilitiral. Leta 1881 je bil imenovan za izrednega profesorja.

Leta 1878 je izšla tretja, popolnoma predelana izdaja njegovega učbenika. V njej sta bila - po besedah Wagnerja (1920, str. 141) - zgradba tal in podnebje upoštevana $\mathrm{V}$ dosti večji meri kot je bil to običaj v tedanjih učbenikih. Iz tega obdobja kaže omeniti še njegovo delo Studie über die Talbildung des östlichen Graubündens und der Tiroler Zentralalpen (Raziskava o oblikovanju dolin v vzhodnem Graubündnu in tirolskih Osrednjih Alpah; Supan, 1877). Z delom Temperaturzonen der Erde (Temperaturne cone na Zemlji; Supan, 1879) se je lotil tudi področja klimatogeografije, s katerim se je kasneje še pogosto ukvarjal. Po navedbah Mittlove (2007, str. 22) naj bi Supanu do znanstvene veljave pomagala ravno njegova klimatološka dela. Na to področje sodita tudi Supanovi deli Die Vertheilung der jährlichen Wärmeschwankung auf der Erdoberfläche (Razporeditev letnih toplotnih nihanj na Zemljinem površju; Supan, 1880a), ki ga je Köppen (Wladimir Peter Köppen, 1846-1940; nemški in ruski geograf, meteorolog, klimatolog in botanik) označil kot prvi uspel poskus kartografskega prikaza te vsebine (Wagner, 1920, str. 141), ter Statistik der unteren Luftströmungen (Statistika vetrov v spodnji troposferi; Supan, 1881).

Na povabilo leipziške založbe Veit \& Co. je nastalo delo Grundzüge der physischen Erdkunde (Osnove fizičnega zemljepisa; Supan, 1884), in sicer v nakladi 500 izvodov (Wagner, 1920, str. 141). Kasneje je bilo večkrat ponatisnjeno v bistveno večjih nakladah in ga je po mnenju mnogih (npr. Wagner, 1920; Dietrich, 1921; Hwang, 2011) mogoče označiti za Supanovo življenjsko delo.

Po smrti Ernsta Behma (1830-1884), soustanovitelja nemške geografske revije Petermanns geographische Mitteilungen (izhajala je pod različnimi nazivi, npr. Mittheilungen 
aus Justus Perthes' Geographischer Anstalt über wichtige neue Erforschungen auf dem Gesammtgebiete der Geographie von Dr. A. Petermann, Dr. A. Petermann's Mittheilungen aus Justus Perthes' Geographischer Anstalt ...), so Supanu ponudili uredništvo revije, ki jo označujeta Caldwell in Schindlmayr (2002) kot »mogoče vodilni svetovni geografski časopis v tistem času« (podobno oznako uporabi Wardenga, 2006). Supan je sprejel ponudbo in po Wagnerjevih besedah (Wagner, 1920, str. 145) »s težkim srcem« prenehal $\mathrm{z}$ akademskim poučevanjem. Tako se je jeseni 1884 preselil v Gotho, sprva le kot glavni urednik revije Petermanns geographische Mitteilungen. Uredniško delo je opravljal skoraj 25 let. Pod njegovim vodstvom je postala revija bolj znanstveno usmerjena (Mittl, 2007, str. 22).

Supan je menil, da mora revija držati korak z razvojem znanosti, zato je uvedel poročila o literaturi, ki jim je sprva posvetil večino svoje pozornosti. V prvih petih letih je sam napisal okrog tri četrtine poročil, in sicer kar okrog 2000 (Wagner, 1920, str. 142). Kasneje si je v ta namen pridobil številne sodelavce. Svojo recenzijsko aktivnost je omejil leta 1889, ko je prevzel uredništvo statističnega letopisa. Tudi po tistem se njegovo ime še zmeraj pojavlja pri 100-120 referatih letno, kljub temu, da mu je pri tej dejavnosti pomagalo 60-80 recenzentov/piscev (Mittl, 2007, str. 23). Istega leta je v obravnavano revijo uvedel Lokalklimatologische Beiträge (Lokalnoklimatološke prispevke), v katerih je predstavljal številne klimatološke notice iz publikacije Meteorologische Zeitschrift in iz drugih virov v obliki enega samega poročila.

$\mathrm{Z}$ naraščanjem produkcije geografske literature je naraščal tudi obseg knjižnih poročil, ki so nazadnje obsegala skoraj polovico revije, zato je ostalo za originalna dela in za poročila o geografskih raziskovanjih razmeroma malo prostora. S tem v zvezi se Wagner (1920, str. 143) sprašuje, ali se ni Supan preveč zaprl pred mnenjem, da je velik poudarek na knjižnih poročilih vplival na upad zanimanja širše publike za revijo. Posebej je treba omeniti številne dopolnilne zvezke revije. V času njegovega urejanja revije jih je izšlo kar 88. Med njimi so prevladovala regionalnogeografska dela.

Supan je v tem obdobju v reviji objavil vrsto del s področja klimatologije in oceanografije, na primer Die mittlere Dauer der Haupt-Wärmeperioden Europas (Srednje trajanje glavnih toplotnih obdobij v Evropi; Supan, 1887), Die jahreszeitliche Verteilung der Niederschläge in Europa, Westasien und Nordafrika (Razporeditev padavin v Evropi, Zahodni Aziji in Severni Afriki po letnih časih; Supan, 1890b), Die Verteilung des Niederschlags auf der festen Erdoberfläche (Razporeditev padavin na kopnem; Supan, 1898a), Die jährlichen Niederschlagsmengen auf den Meeren (Letne količine padavin na morjih; Supan, 1898b), Die Bodenformen des Weltmeeres (Talne oblike svetovnega morja; Supan, 1899), Die arktische Windscheide und die modernen Polarprojekte (Arktična vetrovna ločnica in moderni polarni projekti; Supan, 1891) in druge (npr. Supan, 1889a; 1889b). Napisal je tudi več krajših prispevkov z drugih področij fizične geografije (npr. Supan, 1890a; 1897c). Prispevkov s področja zgodovine odkrivanj se je lotil le izjemoma; takšen primer je delo Ein Jahrhundert der Afrikaforschung (Stoletje raziskovanja Afrike; Supan, 1888), v ta okvir pa sodijo tudi nekateri krajši prispevki (npr. Supan, 1897a; 1897b).

V okviru zbirke regionalnogeografskih monografij Länderkunde von Europa, ki jo je urejal nemški geograf Alfred Kirchhoff (1838-1907), je leta 1889 izšla Supanova 
Avstro-Ogrska. Po mnenju Wagnerja (1920, str. 144) si je z njo Supan zagotovil mesto v prvi vrsti nemških geografov.

Komaj je s tem zaključil, se je za več let posvetil zbiranju statističnih podatkov. To gradivo je želel objaviti v pregledni in dostopni obliki. Začel je z ekonomsko geografijo in načrtoval, da bi v dopolnilnih zvezkih revije Petermanns geographische Mitteilungen oblikoval arhiv za področje ekonomske geografije. Kot primer tovrstnega dela je leta 1886 bralcem ponudil obravnavo gospodarske proizvodnje Severne Amerike in njenega položaja v svetovnem prometu v letih 1880-1885. Sodeloval je tudi pri pripravi osme izdaje Prebivalstva Zemlje (Die Bevölkerung der Erde), ki je izšla leta 1891. V njej je Supan prevzel obravnavo Afrike, Amerike, Avstralije in polarnih dežel. Leta 1893 je ponovno zbral in objavil podatke o prebivalstvu vse Zemlje, kasneje pa je tovrstne podatke objavljal po posameznih območjih oziroma kontinentih. Omenjena dela so izhajala kot dopolnilni zvezki revije Petermanns geographische Mitteilungen. Ko se je preselil v Wrocłav, se s tem ni več mogel ukvarjati, nadomestil pa ga ni nihče. Leta 1889 je prevzel tudi uredništvo statističnega dela publikacije Gothaischer Hofkalender (ki je sicer predstavljala predvsem rodbinske podatke o evropskih plemiških družinah; gl. Gothaischer Hofkalender, 2015).

Leta 1906 je izdal knjigo Die Territoriale Entwicklung der europäischen Kolonien (Ozemeljski razvoj evropskih kolonij; Supan, 1906), ki jo je Wagner (1920, str. 144-145) označil kot »resnično mojstrovino«, ki je enako primerna »za izobraženo publiko kot tudi za kolonialne politike in geografske strokovnjake«. V uvodu v knjigo je Supan (1906, str. III) zapisal:

»Kdor pozna moje prejšnje znanstveno delo, bo mogoče začuden, da me zdaj sreča na zgodovinskem področju. Toda skok ni tako velik, kot bi se lahko sprva zdelo. Ozemeljske spremembe predstavljajo pomemben del vsebine periodičnih zbirnih del Die Bevölkerung der Erde [Prebivalstvo Zemlje], ki jih [...] izdajam od leta 1891 in od začetka sem se trudil kolonialne premike, še posebej v Afriki, obravnavati temeljiteje, kot je bilo prej običajno.«

Leta 1895 je v Gothi izdal delo Deutsche Geographie (Nemška geografija). Pri tem je šlo za prilagoditev njegovega avstrijskega učbenika pruskim učnim načrtom. Delo je doživelo 11 izdaj. Leto kasneje (1896) je izšla 2. izdaja njegovega dela Grundzüge der physischen Erdkunde, ki je bila močno spremenjena in razširjena. Kasneje so sledile nove izdaje tega dela še v letih 1903, 1908, 1911 in 1916.

Leta 1908 so mu ponudili predavateljsko mesto v Wrocławu, čeprav je tedaj imel že 62 let. Vsega skupaj je zaradi zdravstvenih težav uspel predavati samo 10 semestrov. Leta 1911 je (zaradi lažje kapi) izgubil vid na levem očesu, v letih 1914 in 1916 pa ga je še dvakrat zadela kap.

Poleti 1918 je izšlo njegovo zadnje delo Leitlinien der allgemeinen politischen Geographie : Naturlehre des Staates (Smernice splošne politične geografije : prirodoslovje države). Po Wagnerjevi navedbi (1920, str. 146) je imel Supan to svoje delo za najbolj izvirno, kar je v svojem življenju napisal.

Ko je julija 1920 umrl, se ga niso spomnili samo v Nemčiji, kjer sta med drugim izšla prispevka Wagnerja (1920) in Dietricha (1921), ampak tudi drugod po svetu (npr. H. L., 
1920). Wagner je ob tej priložnosti zapisal: »Z Aleksandrom Supanom je spet preminil eden naših najboljših iz starih dobrih časov. Zares, ni zaman živel« (Wagner, 1920, str. 146).

Slika 1: Alexander Georg Supan (1847-1920).

Figure 1: Alexander Georg Supan (1847-1920).

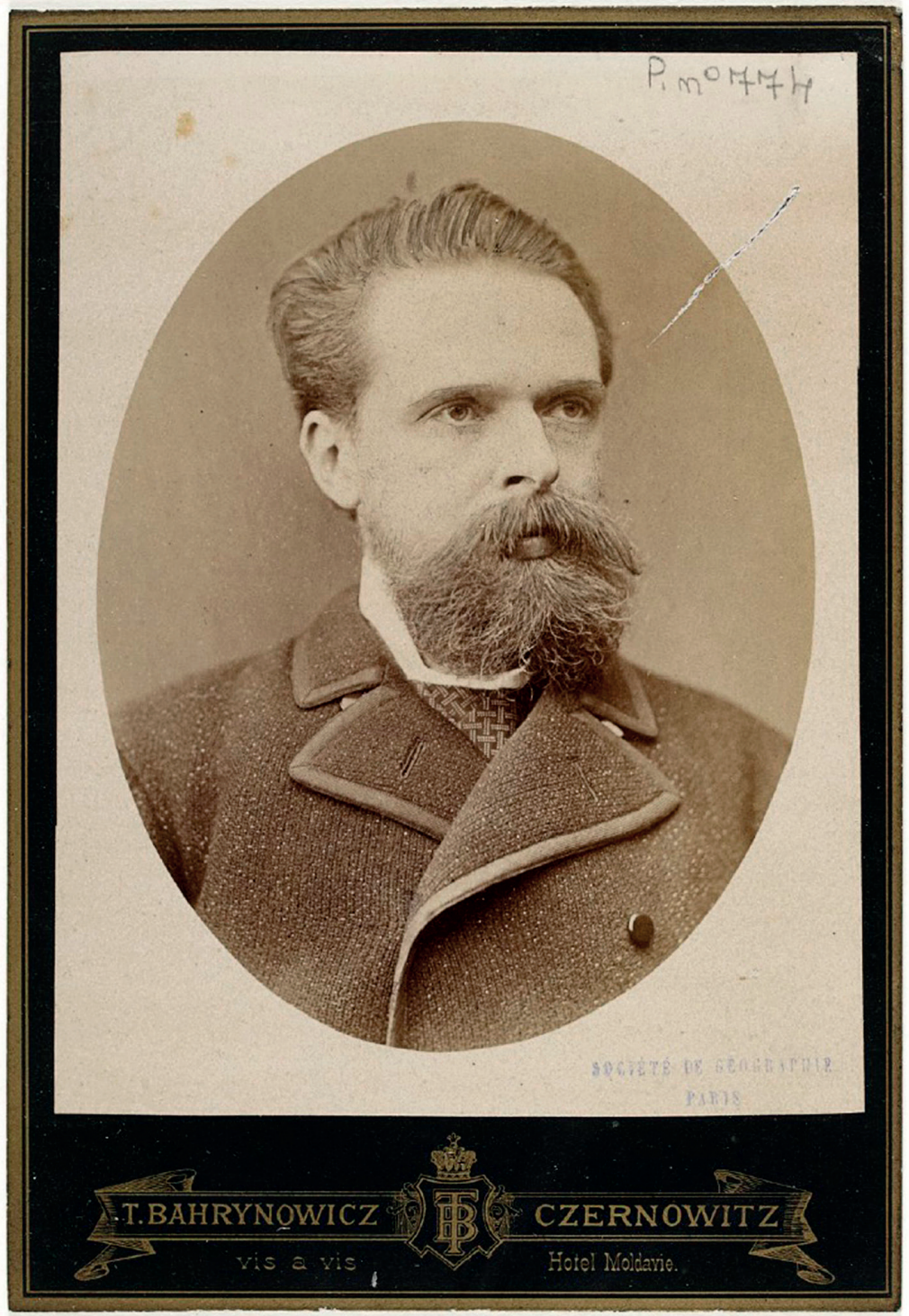

Vir/Source: Bahrynowicz, 1883. 


\section{I Odmevnost in vpliv Supanovega dela}

Supanov vpliv je segel daleč čez meje nemškega jezikovnega območja, o čemer pričajo predstavitve njegovih del v številnih uglednih in vplivnih nenemških geografskih revijah, na primer The Geographical Journal, ki jo izdaja The Royal Geographical Society skupaj z Institute of British Geographers (npr. Supan's Physiography, 1903; J. W. G., 1908; Herbertson, 1899; A. J. S., 1906; M. I. N., 1931), Bulletin of the American Geographical Society (revija je izhajala do leta 1915, izdajatelj je bila American Geographical Society; npr. M. K. G., 1908), Geographical Review, ki jo izdaja American Geographical Society (Bowman, 1924), Journal of the American Geographical Society of New York (Hurlbut, 1893). Hooson (1968) navaja, da je pri svojih univerzitetnih predavanjih v veliki meri uporabljal Supanova dela znan ruski geograf D. N. Anučin (1843-1923), ki je tudi uredil ruski prevod Supanovega dela Grundzüge der physischen Erdkunde. Slednje v okviru gesla o Supanu omenja tudi Velika sovjetska enciklopedija (Большая Советская Энциклопедия ..., 1952), po kateri sta v ruskem jeziku izšli dve izdaji tega Supanovega dela, in sicer v letih 1899 in 1914.

Njegovo delo je doživelo velik odmev v strokovnih krogih že za časa njegovega življenja in v obdobju do druge svetovne vojne, čeprav tudi kasneje ni bilo pozabljeno. Kot ponazoritev širine njegovega dela in vpliva lahko služi podatek, da je na primer v letniku 1912 nemške geografske revije Geographische Zeitschrift bil citiran (ali drugače omenjan) kar v štirih prispevkih z različnih geografskih področij (Hänsch, 1912; Kiaer, 1912; Meinardus, 1912; Hettner, 1912). Pri tem so bila citirana njegova dela Die Bevölkerung der Erde, Die territoriale Entwicklung der europäischen Kolonien in Grundzüge der physische Erdkunde. Tako ne čudi, da je o njem Dietrich (1921, str. 196) zapisal, da »ni področja geografije, na katerem ne bi bil doma«. V isti številki revije se je njegovo ime pojavilo tudi v oceni Davisove in Braunove knjige z naslovom Grundzüge der Physiogeographie (Osnove fiziogeografije). Avtorja recenzije Friederichsena (1912) knjiga Davisa in Brauna kot celota ni zadovoljila. Pri tem je zapisal, da bi mogoče moral nemški sodelavec (tj. Braun) ameriškega kolega opozoriti, »da imamo v Nemčiji učbenike priznanega znanstvenega pomena (pri tem omenjam samo učbenika gospodov Wagnerja in A. Supana) v tolikšnem izobilju, da se morajo nasproti njim odlomki o matematični geografiji, klimatologiji in oceanografiji v Davisovem delu zdeti prav borni.«

V nadaljevanju bodo predstavljeni nekateri odmevi na Supanovo delo, ki ne morejo in ne želijo podati celovite podobe vpliva njegovega znanstvenega in strokovnega opusa, lahko pa služijo za ponazoritev njegovega pomena v okviru geografije, pa tudi drugih ved.

Po mnenju Hwanga (2011, str. 23) se Supana danes najbolj spominjamo po njegovem poimenovanju podmorskih oblik, potem ko je bil leta 1904 sprejet njegov predlog za novo terminologijo s strani mednarodnega geografskega kongresa v Washingtonu, rezultat tega pa je bila prva izdaja Splošne batimetrične karte oceanov. Ne glede na to so tudi v današnji strokovni literaturi pozornosti avtorjev deležna številna njegova dela z različnih vsebinskih področij, še dosti bolj pa je to veljalo za njegove sodobnike.

Že oba avtorja (Wagner, 1920; Dietrich, 1921), ki sta o Supanu pisala ob njegovi smrti, sta omenila njegove poglede na geografijo na splošno in njihovo spreminjanje 
skozi čas. Tako Wagner (1920, str. 141) piše, da je Supan sprva zagovarjal geografijo kot čisto naravoslovno znanost, leta 1895 pa je v svojem delu Deutsche Geographie že nastopil proti prevelikemu poudarjanju naravoslovne strani geografije. V svojem zadnjem delu (Leitlinien der allgemeinen politischen Geographie) je že povsem nasprotoval svojim mladostnim stališčem in je zapisal, da »enostransko morfološki razvoj geografijo zmeraj bolj odtujuje njenemu najbolj notranjemu bistvu« (Wagner, 1920, str. 146). Dietrich (1921, str. 197) je v svojem članku o Supanu zapisal, da je Supan »poudarjal v svojih prvih delih povsem naravoslovni značaj geografije, prepoznal potem regionalno geografijo kot pravi cilj geografije in nazadnje zahteval oživitev politične geografije, ki jo je prej sam zanemarjal. Prej kot drugi je spoznal vrednost ekonomskogeografskega raziskovanja, bolj kot drugi [...] je dal geografskemu okolju napotila k pravemu geografskemu ovrednotenju statistike«.

V strokovni literaturi so bila opažena tudi Supanova stališča o regionalni geografiji (s tem v zvezi gl. tudi Supan, 1889c). Wardenga (2006, str. 137) zapiše, da je Supan videl regionalno geografijo zgolj kot »uvodno stopnjo, skozi katero vstopimo v tempelj splošne geografije, kjer se odvija resnična znanost«. Vpliven ameriški geograf Richard Hartshorne (1899-1992) ga je v svojem obsežnem delu The Nature of Geography (Narava geografije; Hartshorne, 1939) omenjal med tistimi, ki so nasprotovali stališčem (ki so jih izražali npr. Schlitter, Passarge, Sauer ...), da bi se morala geografija pri proučevanju regije omejiti zgolj na njene materialne poteze, Ripley (1895) pa je svoj članek Geography as a sociological study (Geografija kot sociološko proučevanje) zaključil z Supanovo mislijo, da bo vedno eden namenov proučevanja »miljeja« odkrivati, ali je historični razvoj ljudi v skladu z njihovim okoljem in če ne, ali je pozitiven ali negativen dejavnik v napredku.

Zelo veliko pozornosti so bila deležna njegova dela s področja fizične geografije, tako s strani njegovih sodobnikov kot tudi kasneje. Na zelo pozitiven sprejem v tedanji geografski strokovni javnosti je naletelo njegovo »življenjsko delo« Grundzüge der physischen Erdkunde, o čemer pričajo številne ocene. Tako je po mnenju avtorja ocene, ki je bila objavljena v reviji The Geographical Journal (Supan's Phisiography, 1903), Supanova knjiga »eden najboljših, če ne najboljši povzetek sedanjega stanja našega znanja o pojavih na Zemljinem površju« in zaključuje, da gre za nepogrešljivo delo v geografski knjižnici. Podobno pozitivna je ocena J. W. G. (1908), ki je zapisal, da geografija in geografi Alexandru Supanu veliko dolgujejo že za njegovo urejanje revije Petermanns geographische Mitteilungen, da pa je Supan ta dolg še povečal s pripravo »enega najbolj popolnih in aktualnih priročnikov s področja fizične geografije« do tedaj. Tudi Cvijić (1909, str. 386) v svoji recenziji knjige francoskega geografa Emmanuela de Martonneja (1873-1955) zapiše, da se (glede celovitosti obravnave fizične geografije) lahko z njo primerjata le dve knjigi, in sicer Supanova Grundzüge der physischen Erdkunde ter Wagnerjeva Lehrbuch der Geographie. Z drugega zornega kota opozarja na vpliv tega Supanovega dela Beck (1973, str. 286), ki navaja, da so ga študenti, ki so se pripravljali na izpite, uporabljali tudi še v 20. stoletju.

Pozitivnega odmeva v reviji The Geographical Journal (Herbertson, 1899) sta bili deležni tudi Supanovi deli, ki sta obravnavali letno razporeditev padavin nad kopnim in morjem (Die Verteilung des Niederschlags auf der festen Erdoberfläche, Die jährlichen 
Niederschlagsmengen auf den Meeren). Kljub več kritičnim opazkam Herbertson meni, da Supanovo delo Die jährlichen Niederschlagsmengen auf den Meeren (Letne količine padavin na morjih) iz leta 1898 veliko prispeva k poznavanju razporeditve padavin ter zaključuje, da je Supan s tem pripravil »klasično monografijo o padavinah«.

Supanovo fizičnogeografsko delo je bilo na več področjih pionirsko. Dickinson in Howarth (1933) ga v svoji knjigi Making of Geography omenjata kot tistega avtorja, ki je kot drugi pripravil karto izolinij temperaturne amplitude ter kot enega prvih, ki so pripravili svetovno karto izohiet (skupaj s Herbertsonom). Omenjata ga tudi kot avtorja druge celovite klasifikacije podnebij, v kateri je opredelil svetovne podnebne cone s pomočjo izoterm. Herbertson (1899) navaja, da sta Supanovo delo prvi zemljevid padavin na oceanih in prvi svetovni zemljevid sezonskih padavin, Wickramaratne (2008) v svojem prispevku The development history of biogeography (Razvojna zgodovina biogeografije) omenja Supana kot tistega, ki je vpeljal koncept drevesne meje, Kolchak (1928, str. 133) pa v svojem prispevku navaja, da je prva formulacija koncepta arktične vetrovne ločnice Supanovo delo.

Slika 2: Supanova karta januarskih izoterm.

Figure 2: Supan's map of January isotherms.

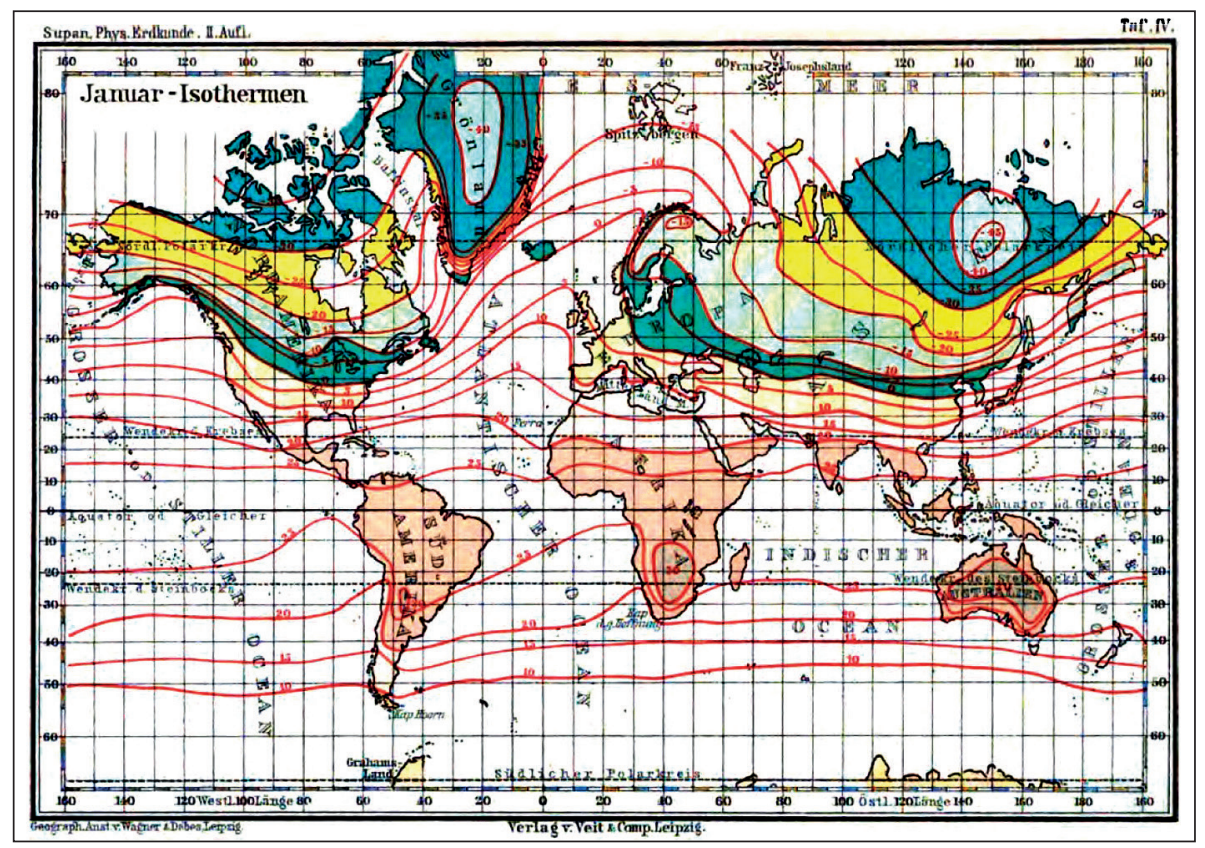

Vir/Source: Supan, 1896.

Pozornost so vzbudila tudi Supanova stališča o Davisovi teoriji o cikličnem razvoju reliefa. Že Dietrich (1921, str. 194) je omenil Supanovo diskusijo z W. M. Davisom in 
njegovo šolo, v novejšem času pa ga Wardenga (2004) v svojem prispevku o razvoju nemške geografije navaja med nasprotniki Davisove teorije.

Tudi Supanova prizadevanja na drugih področjih geografije so bila cenjena v tedanjih strokovnih krogih. M. K. G. (1908) na primer v oceni knjige Die territoriale Entwicklung der europäischen Kolonien navaja, da je »predstavitev velikanskega predmeta načrtovana in izpeljana na občudovanja vreden način«, potem pa dodaja, da »knjiga ne bi bila delo geografa, če bi bila samo kompilacija zgodovinskih podatkov. Njena največja zasluga je $\mathrm{v}$ dejstvu, da je [...] istočasno znanstvena razprava o delovanju geografskih zakonov in zgodovinskega razvoja kolonij.«

Dickinson in Howarth (1933) omenjata Supana kot tistega, ki je za Ratzlom prvi celovito obravnaval področje politične geografije, in sicer v svoji knjigi Leitlinien der allgemeinen politischen Geographie. Medtem ko je bilo v splošnem Supanovo delo deležno predvsem zelo pozitivnih odzivov, so bila mnenja o tej njegovi knjigi bolj deljena. Nekateri avtorji so jo ocenjevali večinoma pozitivno. Tako je Joerg (1922, str. 444) v svojem pregledu »nedavnega geografskega dela v Evropi« zapisal, da je bila na področju družbene geografije (human geography) »najpomembnejša nedavna publikacija Supanov priročnik politične geografije«. Hartshorne (1935, str. 791-792) v svojem delu, v katerem predstavlja tedanji razvoj politične geografije, zapiše, da so političnogeografska dela iz »tega obdobja« odražala pomanjkanje ustreznega razvoja politične geografije kot discipline, pa tudi pomanjkanje osnovnega znanja s tega področja pri večini avtorjev. Navaja pa, da so bile pri tem tudi pomembne izjeme, med katerimi omenja Supana in Pencka, ki sta bila »kljub intenzivnemu nacionalizmu sposobna dati dragocen prispevek k razvoju teorije« na tem področju.

Na drugi strani je bilo o Supanovem zadnjem, političnogeografskem delu tudi precej negativnih mnenj. Vogel (1924) je v svoji recenziji druge, močno predelane izdaje te Supanove knjige mestoma precej kritičen do rezultata. Kot navaja, »številna mesta izdajajo, da [Supan] še ni zaključil z miselnim delom«, hkrati pa meni, da bi - če bi mu bila namenjena daljša življenjska pot - še marsikaj izboljšal. Supan je sicer spoznal potrebo, da se je najprej treba pojmovno lotiti bistva države, kar pa je o tem zapisal, »izdaja vpadljivo pomanjkanje moči filozofske presoje in šolanja« (Vogel, 1924, str. 469).

Bowman (1924, str. 665) je v zvezi s tem delom zapisal, da je Supan v njem dal več prostora domišljiji, »še zlasti pa mnenjem in, žal, predsodkom《 ter nadaljuje: »Časi so se spremenili: stal je na pragu novega, povojnega sveta kot Nemec in je povsod videl opustošenje. Obup, ki ga je čutil, je prenesel na te strani ...«. Supan sam je poudarjal svoje iskanje sistemov oziroma sistematičnosti (Wagner, 1920, str. 140, navaja njegove besede: »Sistem je nasploh značaj moje znanstvene dejavnosti. Mi pač leži v krvi.«), Bowman (1924, str. 665) pa vidi problem Supanove filozofije (tudi) v tem, torej v njegovem »skoraj instiktivnem iskanju sistema«, ki naj bi racionaliziral dejstva, ki jih obravnava politična geografija. Meni, da je videti, kot bi Supan iskal zakone, podobne tistim, ki vladajo v fizičnem svetu. (Takšna stališča avtor recenzije ponavlja tudi v svojem kasnejšem prispevku; Bowman, 1942.) Knjiga se po Bowmanu (1924) konča z grenkobo, ki se nanaša predvsem na nemško izgubo kolonij, ki zanj predstavlja nasilje nad katerimkoli mogočim ekonomskim sistemom. Kljub tem kritičnim besedam pa je Bowman zapisal, da je v tem delu tudi marsikaj »odličnega«. 
Supanova knjiga Leitlinien der allgemeinen politischen Geographie je bila, ne glede na nekatere neugodne odzive, zelo vplivna. S tem v zvezi kaže omeniti tudi to, da $\mathrm{Mu}-$ rphy (1997, str. 141) navaja, da je uporabo izdaje iz leta 1922 v srednjih šolah priporočilo prusko ministrstvo za izobraževanje.

Tudi v novejšem času so Supanova razmišljanja vzbudila pozornost nekaterih avtorjev. Murphy (1999) pri svojem obravnavanju geopolitike in nemškega okoljskega determinizma v obdobju 1900-1933 omenja Supana v zvezi s prepričanjem Nemcev, da so ljudstvo brez prostora. Pri tem navaja, da so uradni visokošolski geografski in zgodovinski teksti dopovedovali študentom (pri tem pa citira Supanovo misel), da je njihova država kot prostorska kreacija »naravna esenca, ki se v svojem sedanjem prostoru sooča z neizogibnim upadom« (Murphy, 1999, str. 126).

V svoji knjigi The Heroic Earth: Geopolitical Thought in Weimar Germany, 19181933 Murphy (1997) razpravlja o Supanovem delu predvsem v zvezi z »organskim konceptom države«, ki je bil priljubljen v okviru geopolitike in politične geografije. Opozarja, da je Supan sicer zavračal enostavno uporabo organskega modela države in celo razpravljal o pomanjkljivostih Ratzlovih in Kjellénovih (Johan Rudolf Kjellén, 18641922) organskih konceptov države, a se je nazadnje vrnil k naslednji definiciji funkcije politične geografije: »Politična geografija ali prirodoslovje države jo [tj. državo] razume kot naravno telo.« Po Murphyjevem mnenju na prvi pogled takšnega pojmovanja ni lahko ločiti od Kjellénovega proučevanja »geografskega organizma« ali Haushoferjeve (Karl Haushofer, 1869-1946) »znanosti o političnih življenjskih oblikah v njihovem naravnem življenjskem prostoru«. Poudarja tudi, da se je mogoče spraševati, ali bi povprečen mlad bralec bil sposoben slediti Supanovim subtilnostim. Po njegovem mnenju lahko Supanov jezik in izražanje samo okrepita predstavo, da je država naravni organizem.

Nadalje Murphy (1997, str. 142) opozarja, da je Supan na tipičen geopolitičen način posvetil velik del svoje politične geografije proučevanju mej in tudi pri tem je podoba države kot organizma zelo živa. Po Murphyjevem mnenju (1997, str. 143) je Supanovo zanašanje na organski model države še posebej jasno v njegovih razlagah praktične vrednosti politične geografije. Pri tem so bile države predstavljene kot osebe z vsemi značilnostmi živih bitij. Višje razvite države so bile opisane kot »esence z zavestno voljo, kot osebnosti«. Politična geografija naj bi razkrivala »stopnjo, do katere naravna situacija krepi ali zavira voljo«. Murphy tudi opozarja, da je Supan razumel politično geografijo kot aplikativno znanost, pridobitev državne moči pa naj bi bil cilj te praktične vede. Zaključi pa z besedami: »Supanov geopolitični poudarek na boju in organskih modelih države je imel destruktivne posledice. Mir med državami, na primer, si je mogoče predstavljati samo kot začasen, in ker je bil boj med državami predstavljen kot večen in neizprosen, bi morala biti pridobitev moči konstanten in prvenstven cilj države « (Murphy, 1997, str. 143).

Še bolj temeljito se je tej Supanovi knjigi posvetil Hwang (2011), ki obravnava razumevanje moči v njej. Pri tem podrobno analizira Supanovo pojmovanje države ter njegovo obravnavanje prebivalstva, prostora in organizacije. Pozornost nameni tudi t. i. »kvocientu pritiska«. Gre za edini novejši prispevek, ki je v celoti osredotočen na to Supanovo knjigo, kar tudi govori o tem, da je lahko njegovo delo še zmeraj zanimivo. 
Supanovo delo Leitlinien der allgemeinen politischen Geographie je našlo odmev tudi med latinskoameriškimi geografi. Zusman in Pereira (2000) v članku, ki je posvečen delu Delgada de Carvalha (Carlos Miguel Delgado de Carvalho, 1884-1980), geografa, ki je deloval v Braziliji, opozarjata na vpliv, ki ga je Supanovo delo imelo nanj. Podobno Reyes Novaes (2015) navaja, da se je na Supanovo političnogeografsko delo opiral tudi brazilski geopolitik in general Carlos de Meira Mattos (1913-2007).

Na velik vpliv Supanove zadnje knjige opozarja tudi to, da Ante (1981, str. 14) v okviru poglavja o razvoju politične geografije namenja Supanu kar pol strani (od skupno 14 strani).

Slika 3: Naslovnica Supanovega učbenika iz leta 1880.

Figure 3: Title page of Supan's textbook from 1880.

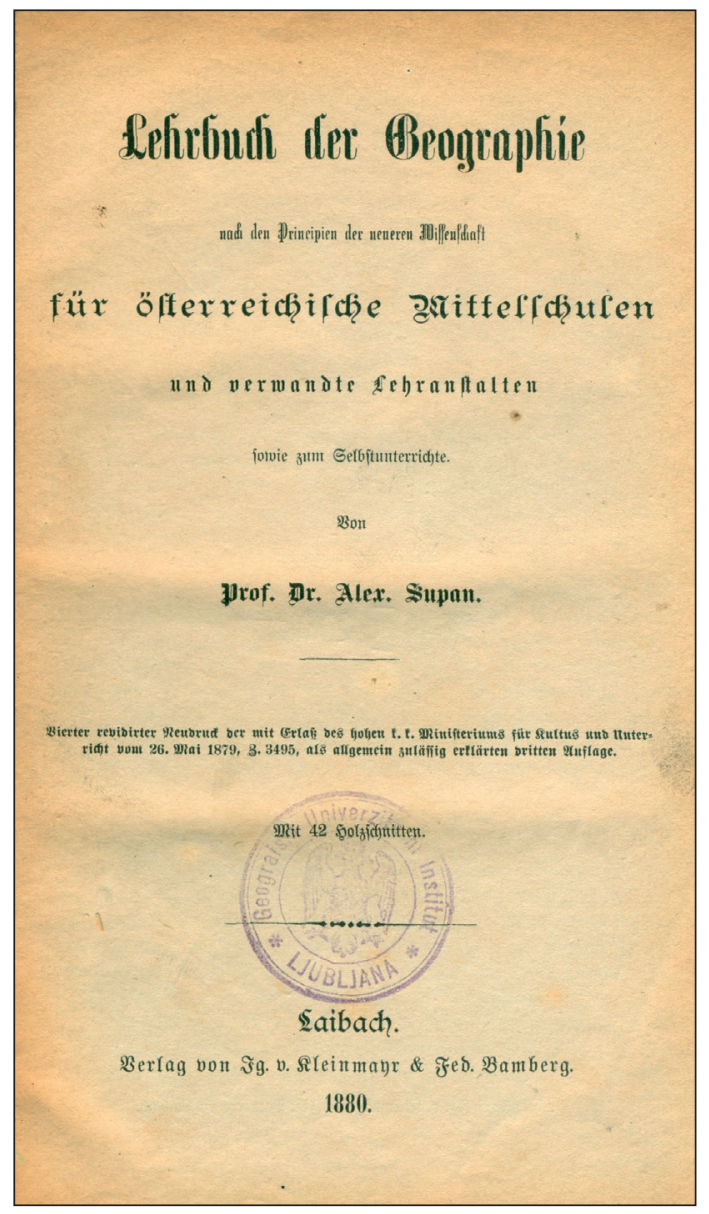

Vir/Source: Supan, $1880 b$. 


\subsection{Supanov vpliv na Slovenskem}

Medtem ko je bil Supan v svetovni geografiji tedanjega časa razmeroma zelo vpliven in se je njegov vpliv ohranil tudi v letih po njegovi smrti, je bilo med slovenskimi geografi njegovo delo v tem obdobju praktično povsem spregledano. O tem priča tudi dejstvo, da v Geografskem vestniku, edini tedanji slovenski geografski reviji, Supan v času med obema svetovnima vojnama (1925-1940) ni bil omenjen niti enkrat. Edina - pa še to samo delna - izjema je predstavitev 1. številke revije Hrvatski Geografski Glasnik, katere avtor je bil Svetozar Ilešič. V zvezi s predstavitvijo enega izmed člankov iz te revije je zapisal (Ilešič, 1928, str. 151):

»Stj. Ratkovič razpravlja o geografskem kvocijentu pritiska, o pojmu, ki ga je v politično geografijo uvedel A. Supan; upravičeno ugotavlja, da sloni na enostranskem precenjevanju le enega faktorja, namreč absolutnega števila prebivalstva sosednjih držav, ne vpošteva pa istotako važnih momentov, kakor so n. pr. matematični in fizikalni položaj države, dolžina meje in njena kakovost, klimske prilike, prirodno bogastvo, poleg absolutnega posebno tudi relativno število prebivalstva (gostota), stopnja gospodarskega razvoja, vojaške organizacije, socijalna struktura in politična zrelost prebivalstva, narodnostne prilike, medsebojno razmerje sosednih držav itd.«

Iz napisanega bi bilo mogoče razbrati, da je Ilešič poznal to Supanovo delo. Nekatera njegova dela je poznal tudi Melik in se nanja skliceval v geografskem opisu Slovenije (1935, 1936). Z izjemo tega je bilo v času med obema svetovnima vojnama Supanovo delo bolj kot ne prezrto, kar skoraj v celoti velja tudi za kasnejša obdobja. Ne glede na to pa je bil v šestdesetih letih 20. stol. v Geografskem vestniku objavljen že omenjeni Kranjčev (1963) članek o Supanu.

\section{SKLEP}

Čeprav je bil Supan slovenskega rodu, se o njem večinoma govori kot o avstrijskem (Wikipedija, 2015; Encyclopedia Britannica ..., 1922) ali nemškem (Большая Советская Энциклопедия ..., 1952) geografu. Njegovo slovensko poreklo omenjajo le redki neslovenski viri, na primer Velika sovjetska enciklopedija (Большая Советская Энциклопедия ..., 1952), Hwang (2011, str. 23) pa navaja slovenski izvor njegovega imena. Tudi Wagner (1920, str. 140) omenja Supanovo slovensko poreklo, a hkrati navaja, da je bil »čisto nemškega prepričanja« in da se je že kmalu navdušil za nemško nacionalno stvar. V knjigi Leitlinien der allgemeinen politischen Geographie najdemo zapise, kot so »nam, Nemcem«, »naša Vzhodna Afrika« (Supan, 1922, str. 47) ipd. Kljub temu se zdi mogoče, da je poreklo vplivalo na njegovo večjo naklonjenost Slovanom, saj je v zaključnih stavkih svojega dela Leitlinien der allgemeinen politischen Geographie (Supan, 1922, str. 195) zapisal: »Ali ne bi bili Germani in Slovani z roko v roki dovolj močni, da bi delovali kot protiutež Anglosaksoncem, Romanom in Japoncem [...]?« 
Supan je zanesljivo sodil med tiste geografe, ki so najbolje poznali svetovno geografsko produkcijo svojega časa. To je med drugim razvidno iz velikega števila recenzij, ki jih je pripravil za revijo Petermanns geographische Mitteilungen. V svojih delih je citiral večino (naj)pomembnejših geografov in drugih strokovnjakov svojega in starejših obdobij (tudi avtorje, omenjene v 2. poglavju, kot so Darwin, Ratzel, Ritter, Somerville, Spencer, von Humboldt ...; gl. npr. Supan, 1896; 1906; 1922). Njegov izredno dober pregled nad tedanjo geografsko produkcijo se odraža tudi v zasnovi in izvedbi takšnih velikopoteznih del, kot je npr. njegova Grundzüge der Physischen Erdkunde, ki se je na celovit in podroben način lotila obravnavanja zelo širokega področja.

Zdi se, da je danes najbolj zanimiv tisti segment njegovega dela, ki sodi na področje, na katerem je bil deležen največje kritike, tj. na področje politične geografije. Verjetno je to tako posledica tega, da gre za delo, ki je bilo za tisti čas precej inovativno (po Supanovi oceni najbolj izvirno izmed vseh njegovih del), kot tudi njegove spornosti, ne nazadnje pa tudi vpliva Supanovega razmišljanja, kakršno je prisotno v knjigi, na razvoj geopolitike in posledično tudi na nemško zgodovino po prvi svetovni vojni.

Supanov vpliv je bil očiten tako na nemškem govornem območju kot drugod po Evropi, pa tudi svetu. O slednjem pričajo odmevi na njegovo delo v Združenih državah Amerike in Braziliji. Mogoče je reči, da je sodil med bolj vplivne geografe svojega časa. Njegov vpliv je bil opazen tudi v južnoslovanskem prostoru, v presenetljivo majhni meri pa v Sloveniji.

Supan je nedvomno geograf, mimo katerega ni mogoče pri obravnavanju razvoja geografije na Slovenskem, vprašljivo pa je, v kolikšni meri ga je mogoče upoštevati pri obravnavanju razvoja slovenske geografije (oziroma geografije v slovenskem jeziku), saj je nanjo le skromno vplival. Kljub temu si zasluži pozornost tudi v takšnem okviru. Njegovo življenje in delo sta rezultat specifičnih razmer tistega časa. Rodil se je slovenskim staršem na ozemlju današnje Italije, šolal na ozemljih današnjih Slovenije, Avstrije in Nemčije, delal pa na območjih današnjih držav Slovenije, Ukrajine, Nemčije in Poljske. Čutil se je predvsem Nemca, a zapisi iz njegove knjige vendarle dajo slutiti, da je na njegova stališča in identiteto vplivala tudi tedaj že izginula Avstroogrska in da je ohranil določeno naklonjenost do Slovanov, kar je bil po poreklu tudi sam.

Opomba: Ocena Supanove knjige Leitlinien der allgemeinen politischen Geographie iz leta 1924 (Bowman, 1924) ni podpisana, a Bowman v svojem delu iz leta 1942 (str. 652) razkriva svoje avtorstvo te ocene.

\section{Literatura in viri}

Ante, U., 1981. Politische Geographie. Braunschweig, Westermann, 244 str.

Bahrynowicz, T. (foto.), 1883. Alexander Supan. URL: http://gallica.bnf.fr/ark:/12148/ btv1b8450104f/ (citirano 14. 10. 2015).

Beck, H., 1973. Geographie. Europäische Entwicklung in Texten und Erläuterungen. Freiburg/München, Verlag Karl Alber, 510 str. 
Blaž Kocen 1821-1871, Življenje in delo očeta Kocenovih atlasov. 2009. Kunaver J. (ur.). Ljubljana, Slovenska matica, 130 str.

Bognar, A., 2001. The theory of geomorphological cycles of William Morris Davis. Geografski zbornik (Acta Geographica), 41, Ljubljana, str. 183-201.

Bohinec, V., 1925. Razvoj geografije v Slovencih. Geografski vestnik, 1, str. 1-24.

Большая Советская Энциклопедия. Второе издание, Том 17. ЗУПАН, Александр (1847-1920). 1952. URL: http://bse2.ru/book_view.jsp?idn=030283\&page=244\&format $=$ html (citirano 19. 1. 2016).

Bowman, I., 1924. Alexander Supan. Leitlinien der allgemeinen politischen Geographie: Natur-lehre des Staates. 2nd edit., edited by Erich Obst. VIII and 199 pp.; maps, diagrs., ill., index. Vereinigung wissenschaftlicher Verleger, Walter de Gruyter \& Co., Berlin and Leipzig, 1922. Geographical Review, 14, 4, str. 665-666.

Bowman, I., 1942. Geography vs. Geopolitics. Geographical Review, 32, 4, str. 646-658.

Bratec Mrvar, R., 2002. Blaž Kocen. Zbornik za zgodovino naravoslovja in tehnike, 1516, str. 162-196.

Bratec Mrvar, R., Kladnik, D., Kunaver, J., Vidrih, R., 2008. Janez Jesenko - pomemben geograf in mislec druge polovice 19. stoletja. Glasnik Slovenske matice, 32 (posebna izdaja), str. 167-181.

Bufon, M., 2001. Osnove politične geografije I: Razvoj politične geografije in geopolitike, globalne razvojne teze ter politična geografija držav in drugih politično-teritorialnih enot. Ljubljana, Oddelek za geografijo, Filozofska fakulteta Univerze v Ljubljani, 201 str.

Caldwell, J. C., Schindlmayr, T., 2002. Historical Population Estimates: Unraveling the Consensus. Population and Development Review, 28, 2, str. 183-204.

Cvijić, J., 1909. Un nouveau traité de géographie physique. Annales de Géographie, 18, 102, str. 385-389.

Dickinson, R. E., Howarth, O. J. R., 1933. The Making of Geography. Oxford, Clarendon Press, 264 str. URL: https://archive.org/details/makingofgeograph009224mbp (citirano 26. 5. 2015).

Dietrich, B., 1921. Alexander Supan. Geographische Zeitschrift, 27, str. 193-198.

Encyclopædia Britannica, Volume 32, Pacific Ocean Islands to Zuloaga. 1922. URL: https://en.wikisource.org/wiki/1922_Encyclop\%C3\%A6dia_Britannica/Supan, Alexander_Georg (citirano 6.10.2015).

Friederichsen, M., 1912. Davis, W. M. und Braun, G. Grundzüge der Physiogeographie. 126 Textabb. u. 1 Taf. Leipzig, Teubner 1911. Geographische Zeitschrift, 18, str. 413-415.

Gams, I., 1992. Ferdinand Seidl - predhodnik slovenske znanstvene regionalne geografije. Geografski vestnik, 64, str. 248-251.

Geoffrey, J. M., Preston, E. J., Eileen, W. J. 1993. All possible worlds: a history of geographical ideas. New York, John Wiley and Sons, 585 str.

Gothaischer Hofkalender. URL: https://de.wikipedia.org/wiki/Gothaischer_Hofkalender (citirano 14. 10. 2015).

H. L., 1920. Alexander G. Supan, 1847-1920. Monthly Weather Review, 48, 10, str. 601. URL: http://docs.lib.noaa.gov/rescue/mwr/048/mwr-048-10-0601c.pdf (citirano 6 . 10. 2015). 
Hänsch, F., 1912. Die Aufteilung Afrikas. Geographische Zeitschrift, 18, str. 361-387.

Hartshorne, R., 1935. Recent Developments in Political Geography. The American Political Science Review, 29, 5, str. 785-804.

Hartshorne, R., 1939. The Nature of Geography: A Critical Survey of Current Thought in the Light of the Past. Annals of the Association of American Geographers, 29, 3, str. $173-412$.

Herbertson, A. J., 1899. Prof. Supan on the Rainfall of the Globe. The Geographical Journal, 13, 1, str. 61-64.

Herbertson, A. J., 1913-1914. Natural Regions. Geographical Teacher, 7, str. 158-163.

Hettner, A., 1912. Alter und Form der Täler. Geographische Zeitschrift, 18, str. $665-682$.

Holt-Jensen, A., 1981. Geography: Its history and Concepts. London, Harper and Row Publishers, 167 str.

Hooson, D. J. M., 1968. The Development of Geography in Pre-Soviet Russia. Annals of the Association of American Geographers, 58, 2, str. 250-272.

Hurlbut, G. C., 1893. Geographical Notes. Journal of the American Geographical Society of New York, 25, 1, str.138-174.

Hwang, K., 2011. Power in Alexander Supan's Guidelines to General Political Geography (1918/1920). Przegląd Geopolityczny, 3, str. 23-44.

Ilešič, S., 1928. Hrvatski Geografski Glasnik, broj 1. Geografski vestnik, 4, str. 151.

Ilešič, S., 1960. Ob sedemdesetletnici profesorja Antona Melika. Geografski vestnik, 32, str. 3-9.

Ilešič, S., 1969: Geografija. V: Modic, T. (ur.). Petdeset let slovenske univerze v Ljubljani 1919-1969. Ljubljana, Univerza, str. 231-242.

Ilešič, S., 1979. Pogledi na geografijo. Teoretsko-metodološki prispevki, razprave in poročila. Ljubljana, Partizanska knjiga, 612 str.

J. S., 1906. History of Colonization. Die Territoriale Entwicklung der Europäischen Kolonien by Alexander Supan. The Geographical Journal, 28, 6, str. 629.

J. W. G., 1908. Supan's Physical Geography. Grundzüge der Physischen Erdkunde by Alexander Supan. The Geographical Journal, 31, 3, str. 327-328.

Jesenko, J., 1874. Prirodoznanski zemljepis. Ljubljana, Matica Slovenska, 399 str.

Joerg, W. L. G., 1922. Recent Geographical Work in Europe. Geographical Review, 12, 3, str. 431-484.

Kiaer, A. N., 1912. Bevölkerungsstatistik der Länder ohne Volkszählung. Geographische Zeitschrift, 18, str. 214-219.

Kolchak, A.,1928. The Arctic pack and polynya. V: Joerg, W. L. G. (ur.). Problems of polar research. New York, American Geographical Society, str. 125-141.

Kranjec, S., 1963. Aleksander Supan, nemški geograf slovenskega rodu. Geografski vestnik, 35, str. 65-69.

Kranjec, S., 1964. Geografija. V: Bernik, F., Melik, A., Kranjec, S., Murko, V. (ur.). Slovenska matica, 1864-1964, Zbornik razprav in člankov. Ljubljana, Slovenska matica, str. 195-219. 
Kranjec, S., 1971. Supan, Aleksander Jurij (1847-1920). Slovenska biografija. Slovenska akademija znanosti in umetnosti, Znanstvenoraziskovalni center SAZU, 2013. URL: http://www.slovenska-biografija.si/oseba/sbi630132/ (citirano 26. 5. 2015).

M. I. N., 1931. Grundzüge der Physischen Erdkunde Band II by Alexander Supan; Erich Obst. Geographical Journal, 77, 5, str. 483-484.

M. K. G., 1908. Die territoriale Entwicklung der europaischen Kolonien. Mit einem kolonialgeschichtlichen Atlas von 12 Karten und 40 Kartchen im Text by Alexander Supan. Bulletin of the American Geographical Society, 40, 11, str. 699-702.

Mahnič, J., 2009. Pomen Slovenske matice za razvoj geografije (Uvodni nagovor k simpoziju o Kocenu). V: Kunaver, J. (ur.). Blaž Kocen 1821-1871, Življenje in delo očeta Kocenovih atlasov. Ljubljana, Slovenska matica, str. 11-12.

Meinardus, W., 1912. O. Krümmels Handbuch der Ozeanographie. Geographische Zeitschrift, 18, str. 29-47.

Melik, A., 1935. Slovenija, geografski opis. 1. splošni del, 1. zvezek. Ljubljana, Slovenska matica, 393 str.

Melik, A., 1936. Slovenija, geografski opis. 1. splošni del, 2. zvezek. Ljubljana, Slovenska matica, str. 394-701.

Mittl, K., 2007. Baedekers Reisehandbücher. Funktionen und Bewertungen eines Reisebegleiters des 19. Jahrhunderts. Erlangen, Nürnberg, Buchwissenschaft/Universität Erlangen-Nürnberg, 149 str.

Murphy, D. T., 1997. The Heroic Earth: Geopolitical Thought in Weimar Germany, 19181933. Kent, Kent State University Press, 338 str.

Murphy, D. T., 1999. 'A sum of the most wonderful things': Raum, geopolitics and the German tradition of environmental determinism, 1900-1933. History of European Ideas, 25, str. 121-133.

Natek, K., 2001. The life and work of William Morris Davis (1850-1934) (Življenje in delo Williama Morrisa Davisa (1850-1934)). Geografski zbornik (Acta geographica), 41, str. 154-165.

Österreichisches Biographisches Lexikon 1815-1950 Online-Edition und Österreichisches Biographisches Lexikon ab 1815 (2. überarbeitete Auflage - online). URL: http://www.biographien.ac.at/oebl_14/51.pdf (citirano 10.9. 2015).

Reyes Novaes, A., 2015. A Geopolítica pelas Imagens. Linguagem Cartográfica e Circulação de Ideias Geopolíticas no Brasil. Terra Brasilis (Nova Série), 6. URL: https:// terrabrasilis.revues.org/1722 (citirano 12. 1. 2016). DOI : 10.4000/terrabrasilis. 1722.

Ripley, W. Z., 1895. Geography as a Sociological Study. Political Science Quarterly, 10, 4, str. 636-655.

Stoddart, D. R., 1966. Darwin's Impact on Geography. Annals of the Association of American Geographers, 56, 4, str. 683-698.

Stoddart, D. R., 1981 (ur.). Geography, Ideology and Social Concern. Basil Blackwell, $256 \mathrm{str}$.

Supan, A., 1877. Studie über die Talbildung des östlichen Graubündens und der Tiroler Zentralalpen. Mitteilungen der Kaiserlich-Königlichen Geographischen Gesellschaft, 20, str. 293-399. 
Supan, A., 1879. Die Temperaturzonen der Erde. Dr. A. Petermann's Mittheilungen aus Justus Perthes' geographischer Anstalt, 25, str. 349-358.

Supan, A., 1880a. Die Vertheilung der jährlichen Wärmeschwankung auf der Erdoberfläche. Zeitschrift für wissenchaftliche Geographie, 1, str. 141-156.

Supan, A., 1880b. Lehrbuch der Geographie nach den Prinzipien der neuren Wissenchaft für Österrerichische Mittelschulen und verwandte Lehranstalten sowie zum Selbstunterrichte. Ljubljana (Laibach), Verlag von Ig. v. Kleinmayr \& Fed.Bamberg, 296 str.

Supan, A., 1881. Statistik der unteren Luftströmungen. Leipzig, Duncker \& Humblot, 296 str. Supan, A., 1884. Grundzüge der physischen Erdkunde. Leipzig, Veit \& Comp., 492 str.

Supan, A., 1887. Die mittlere Dauer der Haupt-Wärmeperioden Europas. Dr. A. Petermanns Mitteilungen aus Justus Perthes' geographischer Anstalt, 33, str. 165-172.

Supan, A., 1888. Ein Jahrhundert der Afrikaforschung. Zum hundertjährigen Gedenktag der Gründung der African Association. Dr. A. Petermanns Mitteilungen aus Justus Perthes' geographischer Anstalt, 34, str. 161-188.

Supan, A., 1889a. Das kalte Wasser an den Luvküsten. Dr. A. Petermanns Mitteilungen aus Justus Perthes' geographischer Anstalt, str. 170-171.

Supan, A., 1889b. Die Tiefenkarte des Indischen Ozeans. Dr. A. Petermanns Mitteilungen aus Justus Perthes' geographischer Anstalt, str. 168-170.

Supan, A., 1889c. Über die Aufgaben der Spezialgeographie und ihre gegenwärtige Stellung in der geographischen Literatur. Dr. A. Petermanns Mitteilungen aus Justus Perthes' geographischer Anstalt, 35, str. 153-157.

Supan, A., 1890a. Schwankungen der Erdachse. Dr. A. Petermanns Mitteilungen aus Justus Perthes' geographischer Anstalt, 36, str. 132.

Supan, A., 1890b. Die jahreszeitliche Verteilung der Niederschläge in Europa, Westasien und Nordafrika. Dr. A. Petermanns Mitteilungen aus Justus Perthes' geographischer Anstalt, 36, str. 296-297.

Supan, A., 1891. Die arktische Windscheide und die modernen Polarprojekte. Dr. A. Petermanns Mitteilungen aus Justus Perthes' geographischer Anstalt, str. 191-195.

Supan, A., 1896. Grundzüge der physischen Erdkunde. Leipzig, Veit \& Comp., 706 str.

Supan, A., 1897a. Die Norwegische Polarexpedition, 1893-96. Dr. A. Petermanns Mitteilungen aus Justus Perthes' geographischer Anstalt, 43, str. 128-132, 153-163.

Supan, A., 1897b. Unbekannte Polargebiete. Dr. A. Petermanns Mitteilungen aus Justus Perthes' geographischer Anstalt, 43, str. 15-18.

Supan, A., 1897c. Vorschläge zur systematischen Erdbebenforschung in den einzelnen Ländern. Dr. A. Petermanns Mitteilungen aus Justus Perthes' geographischer Anstalt, 43, str. $112-115$.

Supan, A., 1898a. Die Verteilung des Niederschlags auf der festen Erdoberflache, Dr. A. Petermanns Mitteilungen aus Justus Perthes' geographischer Anstalt, Erganzungsheft, 124, 103 str.

Supan, A., 1898b. Die jährlichen Niederschlagsmengen auf den Meeren. Dr. A. Petermanns Mitteilungen aus Justus Perthes' geographischer Anstalt, 44, str. 179-182.

Supan, A., 1899. Die Bodenformen des Weltmeeres. Dr. A. Petermanns Mitteilungen aus Justus Perthes' geographischer Anstalt, 45, str. 177-188. 
Supan, A., 1906. Die Territorriale Entwicklung der europäischen Kolonien. Gotha, Justus Perthes, 344 str.

Supan, A., 1922. Leitlinien der allgemeinen politischen Geographie. Naturlehre des Staates. Berlin, Leipzig, Vereinigung wissenschaftlicher Verleger, Walter de Gruyter \& Co., 199 str.

Supan's Physiography. 1903. The Geographical Journal, 22, 6, str. 694-695.

TheFreeDictionary's Encyclopedia. 2015. URL: http://encyclopedia2.thefreedictionary. com/alexander+supan (citirano 10. 9. 2015).

Vogel, W., 1924. Politische Geographie. Weltpolitisches Handbuch by Arthur Dix; Leitlinien der allgemeinen politischen Geographie. Naturlehre des Staates by Alexander Supan; La Terre et l'Évolution humaine. Introduction géographique à l'histoire by Lucien Febvre; Der Kampf um den Erdball by Johannes Wütschke; Weltwirtschaftliche und politische Erdkunde. Historische Zeitschrift, 130, 3, str. 465-473.

Vresk, M., 1991. Paradigme u geografiji. Geografski glasnik, 53, str. 19-26.

Vresk, M., 1997. Uvod u geografiju, razvoj, struktura, metodologija. Zagreb, Školska knjiga, 304 str.

Vrišer, I., 1969. Uvod v geografijo, osnove geografskega dela. Ljubljana, Univerza v Ljubljani, Filozofska fakulteta, 504 str.

Vrišer, I., 1976. Uvod v geografijo. Ljubljana, Filozofska fakulteta, Univerza v Ljubljani, PZE za geografijo, 387 str.

Vrišer, I., 1982. Uvod v geografijo. Ljubljana, Filozofska fakulteta, Univerza Edvarda Kardelja, Oddelek za geografijo, 414 str.

Vrišer, I., 1987. Uvod v geografijo. Ljubljana, Filozofska fakulteta, Univerza Edvarda Kardelja, Oddelek za geografijo, 458 str.

Vrišer, I., 1992. Uvod v geografijo. Ljubljana, Filozofska fakulteta, Univerza v Ljubljani, Oddelek za geografijo, 458 str.

Vrišer, I., 1998. Uvod v geografijo. Ljubljana, Filozofska fakulteta, Univerza v Ljubljani, Oddelek za geografijo, 414 str.

Vrišer, I., 2002. Uvod v geografijo. Ljubljana, Filozofska fakulteta, Univerza v Ljubljani, Oddelek za geografijo, 414 str.

Wagner, H., 1920. Aleksander Supan. Dr. A. Petermanns Mitteilungen aus Justus Perthes' geographischer Anstalt, 66, 7/8, str. 139-146.

Wardenga, U., 2004. The influence of William Morris Davis on geographical research in Germany. GeoJournal, 59, str. 23-26.

Wardenga, U., 2006. German geographical thought and the development of Länderkunde. Inforgeo, 18/19, str. 127-147.

Wickramaratne, S. N., 2008. The development history of biogeography. Vidyodaya Journal of Humanities and Social Science, 2, str. 249-272.

Wikipedija. 2015. URL: www.wikipedia.org (citirano 10. 9. 2015).

Zusman, P., Pereira, S. N., 2000. Entre a Ciência e a Política. Um olhar sobre a Geografia de Delgado de Carvalho. Terra Brasilis (Nova Série), 1. URL: https://terrabrasilis. revues.org/288 (citirano 12. 1. 2016). DOI: 10.4000/terrabrasilis.288. 


\section{ALEXANDER GEORG SUPAN - GEOGRAPHER OF SLOVENIAN ORIGIN, OVERLOOKED IN SLOVENIA}

\section{Summary}

Alexander Georg Supan (1847-1920) was born in South Tyrol (present-day Italy) to Slovenian parents. His father was a forester. Supan attended high school in Ljubljana (present-day Slovenia) and finished study of history and letters in Graz (Austria), where he was awarded $\mathrm{PhD}$. He began his professional career as a history, geography and German language teacher in Ljubljana, where his professional interest became entirely focused on geography. Already as a teacher he followed modern geographical work which was in the second half of the 19th century, under the influence of Darwinism, focused especially on physical geography and environmental determinism, and he wrote the textbook Lehrbuch der Geographie nach den Principien der neueren Wissenchaft für österreichische Mittelschulen (Textbook on Geography after the principles of the new science for Austrian high schools). Because of the fact that in the second half of the 19th century Ljubljana did not have a university, Supan felt a scientific isolation. To overcome it, he took leave to perform additional studies in Graz, Halle and Leipzig. After his transfer to Chernivtsi (Czernowitz; today Ukraine) he was appointed professor of geography at the University of Czernowitz.

He began his scientific career with geomorphological and climatological studies, with which he soon acquired a scientific reputation. In 1884 he published his work Grundzüge der physischen Erdkunde (Principles of Physical Geography) which was afterwards released in many editions. In the opinion of many it was his master work. In the same year he moved to Gotha (Germany). He took over editorship of geographical journal Petermanns geographische Mitteilungen which had the reputation of being one of the leading geographical journals in the world. He remained its editor for almost 25 years. Despite his work as the journal's editor he continued his research work and published numerous professional and scientific works. He focused his attention to climatology, oceanography, economic geography and collecting of statistical data. He also wrote a regional geographic monograph on Austria-Hungary. Thanks to the latter he secured himself one of the leading roles among German geographers. In the last period of his life he dedicated his work to political geography. In 1918 his last book, Leitlinien der allgemeinen politischen Geographie : Naturlehre des Staates (Guidelines to general political geography : natural science of the state), was published. Supan considered it his most original work.

Supan's work acquired high reputation and remained influential at least till World War Two. It was read and cited in German speaking countries and elsewhere, from United Kingdom, USA, and Brasil to Russia. He was among the most respected geographers of his time and his work was consistent with contemporary geographical thought. He was also among better connoisseurs of geographical knowledge and research in the world. This helped him in writing such an ambitious work as Grundzüge der physischen Erdkunde. He was of Slovenian origin, but soon became enthusiastic adherent of the proGerman national cause. Because of that, he is usually considered Austrian or German geographer. Only rarely his Slovenian origin is mentioned. 
His German national orientation and the fact that during his life time geographical science in Slovenian ethnic territory was only poorly developed are among the reasons that his work did not meet with a wide response among Slovenian geographers. In contrast with the countries where geographical science was more advanced, in Slovenian ethnic territory till the end of World War One descriptive regional geography (which has for its main goal to raise Slovenian national consciousness and strengthen political unification of Slovenian territories) was dominant. Despite the fact that Supan spent the majority of his professional career outside of the present-day Slovenian territory and that he wrote in German language he is, because of his origin and beginnings of his career in Ljubljana, doubtlessly also part of the history of geography in Slovenia and deserves within it a special position.

(Translated by the authors) 